\title{
Effect of Organic and Inorganic Nutrient Sources on Productivity, Grain Quality of Rice and Soil Health in North-West IGP: A Review
}

\author{
Shipra Yadav ${ }^{1 *}$, Mohan Lal', R.K. Naresh ${ }^{1}$, R.B. Yadav ${ }^{1}$, Ashok Kumar $\operatorname{Yadav}^{2}$, \\ K.G. Yadav ${ }^{3}$, Rahul Kumar ${ }^{1}$, M. Sharath Chandra ${ }^{1}$ and Pradeep Rajput ${ }^{1}$ \\ ${ }^{1}$ Department of Agronomy, Sardar Vallabhbhai Patel University of Agriculture \& Technology, \\ Meerut (U.P.) India \\ ${ }^{2}$ Department of Soil Science \& Agricultural Chemistry, Sardar Vallabhbhai Patel University \\ of Agriculture \& Technology, Meerut (U.P.) India \\ ${ }^{3}$ Directorate of Extension, Sardar Vallabhbhai Patel University of Agriculture \& Technology, \\ Meerut (U.P.) India \\ *Corresponding author
}

\section{Keywords}

Rice productivity, Integrated nutrient management, Grain quality, Soil heath

\section{Article Info}

Accepted:

15 November 2019

Available Online:

10 December 2019

\section{A B S T R A C T}

Nutrient supply is the most limiting factor next to the water for crop production. Sustaining rice production has become a great challenge, particularly in areas where rice productivity declines in spite of following recommended nutrient management practices. Nutrient management by integrating organic sources of nutrients along with inorganic fertilizers may play an important role in improving and sustaining rice productivity moreover, chemical fertilizers will play a major role as these contribute about $50 \%$ to the increase in food grain production for ever increasing population of our country. Successful nutrient management can optimize crop yields, increase profitability and minimizes nutrient losses. Organic fertilizer improves physical and biological activities of soil but they have comparatively low in nutrient content, so larger quantity is required for plant growth. However, inorganic fertilizer is usually immediately and fast containing all necessary nutrients that are directly accessible for plants. But continuous use of inorganic fertilizers alone causes soil organic matter: degradation, soil acidity and environmental pollution. So the integrated nutrient management system is an alternative system for the sustainable and cost-effective management of soil fertility by combined apply of inorganic with organic materials resulting in rising soil fertility and productivity without affecting environment. Treatment $\mathrm{T}_{6}$ increased the net photosynthesis rate, total biomass, grain yield, and amylose content by $23 \%, 90 \%, 95 \%$, and $10 \%$, respectively, compared with control. This increment in growth was the result of $14 \%, 19 \%$, and $20 \%$ higher total root length, root surface area, root volume, and root diameter, respectively. Improvements in these attributes further enhanced the grain yield and nitrogen use efficiency of rice.The application of organic manure alone or along with bio-fertilizers inoculation significantly improved the $\mathrm{N}, \mathrm{P}, \mathrm{K}$ and $\mathrm{S}$ uptake by rice over control. However maximum improvement in soil health related to available nutrient status, soil microorganism population was observed in organic nitrogen sources alone or along with bio-fertilizers. The $50 \%$ organic fertilizer and $50 \% \mathrm{CF}$ led to increased NPK availability and rice yields over the $100 \% \mathrm{CF}$ treatment, reducing $\mathrm{CF}$ usage and leading for sustainable agriculture. This review provides a sustainable nutrient management strategy to improve crop yield with high nutrient use efficiency. 


\section{Introduction}

Rice is staple food crop of Asian population and in India, area, production and productivity of rice is $43.79 \mathrm{mha}, 112.91 \mathrm{mt}$ and $2.57 \mathrm{t} / \mathrm{ha}$, respectively (Anonymous, 2018). Nutrient supply is the most limiting factor next to the water for crop production. Sustaining rice production has become a great challenge, particularly in areas where rice productivity declines in spite of following recommended nutrient management practices. Nutrient management by integrating organic sources of nutrients along with inorganic fertilizers may play an important role in improving and sustaining rice productivity (Mondal et al., 2016), moreover, chemical fertilizers will play a major role as these contribute about $50 \%$ to the increase in food grain production for ever increasing population of our country (Mahajan and Gupta, 2009). Successful nutrient management can optimize crop yields, increase profitability and minimizes nutrient losses. With the progress of science when we think about Green-energy, sustainability, and environmental safety, we should have a look on modern tools to integrate nutrient management. The decline in the rice crop responses to applied fertilizer nutrients, inter alia, could be ascribed to emerging nutrient deficiencies on account of modern era of agriculture and inadequate or imbalanced application of fertilizers. It has become increasingly recognized around the world that $\mathrm{N}, \mathrm{P}$ and $\mathrm{K}$ fertilizers alone are not always sufficient to provide balanced nutrition for optimal rice yields and quality, therefore, application of secondary and micronutrient elements has to be made. Comparing western U.P. and Punjab in the north and Tamil Nadu in the south, the $\mathrm{N}: \mathrm{P}_{2} \mathrm{O}_{5}: \mathrm{K}_{2} \mathrm{O}$ consumption ratio is much wider in western U.P. and Punjab (42.6:11.9:1.0) as compared to Tamil Nadu (2.6:1.0:1.0). This indicates that the highest fertilizer consuming states have the greatest imbalanced use of nutrients. The main reason of the variation in fertilizer consumption ratios in north and south is due to the nature of soils and cropping pattern. About $35 \%$ of total fertilizer is consumed by rice in India (Datta et al., 2010).

Cultivation of high yielding dwarf varieties responsive to fertilizer and irrigation in intensive cropping after green revolution with continuous and excess use of inorganic fertilizers has depleted the inherent soil fertility. The decline or stagnation in yield has been attributed to nutrient mining and reduced use of organics (John et al., 2001). Several long-term experiments all over India indicated a decrease in rice productivity due to continuous use of chemical fertilizers. Integrated nutrient management (INM) aims to improve soil health and sustain high level of productivity and production (Prasad et al., 1995). Farmyard manure (FYM) is being used as major source of organic manure in field crops as it supplies all essential plant nutrients and increases activities of microbes in soil (Sutaliya and Singh, 2005). Limited availability of FYM is however an important constraint in its uses as source of nutrients. Sharma (2002) reported increased yield and nutrient use efficiency in rice with organics. Organics supply nutrients at the peak period of absorption, and also provide micro nutrients and modify soil- physical behaviour as well as increase the efficiency of applied nutrients (Pandey et al., 2007). It is widely recognized that neither use of organic manures alone nor chemical fertilizers can achieve the sustainability of the yield under the modern intensive farming. Contrary to detrimental effects of inorganic fertilizers, organic manures are available indigenously which improve soil health resulting in enhanced crop yield. However, the use of organic manures alone might not meet the plant requirement due to presence of relatively low levels of nutrients. Therefore, in order to make the soil well supplied with all the plant nutrients in the 
readily available form and to maintain good soil health, it is necessary to use organic manures in conjunction with inorganic fertilizers to obtain optimum yields (Ramalakshmi et al., 2012).

Nitrogen is the most important nutrient and varying organic and inorganic nitrogen sources have significant effect and crucial role on quality of rice grain. Integrated nutrient management including biofertilizers, organics and chemical fertilizers may improve productivity and the quality of rice grain. Biofertilizers alone or in combinations with organic manures improve the quality parameters of scented rice (Dixit and Gupta, 2000; Quyen and Sharma, 2003). Head rice recovery and alkali value of scented rice varieties improved due to application of farmyard manure (Pandey et al., 1999). Lower doses of organic manures improved the quality parameters like hulling, milling and head rice recovery than higher doses (Saha et al., 2007). Milling, head rice recovery, kernel length and length: breadth ratio after cooking of rice significantly improved when organic manures applied in combination with inorganic (Pandey et al., 1999; Quyen and Sharma, 2003; Shrivastava et al., 2009).

\section{Effect of integrated nutrient management on rice yield attributes and yield}

Yadav et al., (2005) further reported that rice yield was maximum with $25 \% \mathrm{~N}$ substitution through green leaf manure $+100 \%$ NPK fertilizer in rice-wheat cropping system. Mehedi et al., (2011) further conclude that sesbania at 20 tha $^{-1}+75 \%$ recommended dose of chemical fertilizer proved to be the best combination to get reasonable yield. Greater tiller number, filled grains per panicles , 1000grain weight and an optimum yield of rice was obtained by application of 120: 60: $45 \mathrm{~kg} \mathrm{~N}$ : $\mathrm{P}_{2} \mathrm{O}_{5}: \mathrm{K}_{2} \mathrm{O}$ ha $^{-1}$ in combination with farm yard manure than the individual sources of NPK and control (Satyanarayana et al., 2002). Virdia and Mehta (2008) reported that application of press-mud @ 20 t/ha along with recommended dose of fertilizer gave the highest grain yield which was on par with press-mud @ 15 t/ha + RDF in 2000 and 2005 and with or FYM @ 10 t/ha + RDF in 1995 (Table 1). This might be due to improvement in nutrient supply with more organics, which improves soil physic-chemical and biological properties by providing essential food to microbes (Sutaliya and Singh, 2005). The liquid organic manures contains small amount of nutrients and growth boosters. When it applied to the crops it removes the imbalances in terms of physical, chemical and physiological aspects and harmonizes the basic element which revitalizes the growth process (Natarajan, 2008). Application of soil + mine spoil + coir pith vermicompost $(1: 1: 1)+$ RDF significantly enhanced plant height $(27.2 \mathrm{~cm})$, number of leaves (33.3), and yield per plant (38.5g), as compared to mine spoil alone + RDF. Somasundaram et al. (2003) application of panchagavya @ 3\% significantly increased grain yield $(17.7 \mathrm{q} / \mathrm{ha})$, number of seed per pod (12.1) and 100 grain weight $(4.0 \mathrm{~g})$ as compared to application of recommended dose of fertilizer. The result revealed that the yield components viz., productive tillers/hill, panicle length, filled grain panicle, seed test weight, grain yield and straw yield were found significantly higher in the treatment of panchgavya spray @ 3\% Yadav and Christophe (2006).

Application of 33t FYM 8t neem cake/ha significantly increases the grain yield (20.5 $\mathrm{q} / \mathrm{ha}$ ) and straw yield (24.5 q/ha) of soybean. Whereas, the highest crude protein (19.3\%) observed in the treatment received the nutrients based on STCR target $25 \mathrm{q} / \mathrm{ha}$ (50145:43 NPK kg/ha) Patil et al., (2008). Kagne et al., (2008) observed that application of vermicompost @ 2.5 t/ha along with seed treatment of Azospirillum and PSB enhanced 
the growth and quality of sorghum and produced highest seed yield (21.7 q/ha). application of $50 \%$ RDN $+50 \% \mathrm{~N}$ through FYM, VAM and PSB @ $12.5 \mathrm{~kg} / \mathrm{ha}+$ panchagavya @ 3\% spray recorded significantly higher number of branches/plant, number of fruits/plant, fruit length and fruit yield as compared to RDF. Kumar and Haefele (2013) reported that application of nitrogen at $90 \mathrm{~kg}$ level as 50\% through Rice straw compost $+50 \%$ nitrogen as poultry manure registered higher growth, grain and straw yield. However, with regard to $\mathrm{N}$ management, LCC 4 and 5 based On $\mathrm{N}$ applications recorded higher grain yield as a result of higher soil available nutrients during the critical growth stages. Venkatalakshmi et al., (2009) observed that foliar application of panchagavya @3\% significantly increased number of leaves, LAI, green leaf yield and dry matte yield of Amaranthus viride and also higher result indicated that when panchagavya applied@3\% and 6\% with seed soaking treatment recorded 11 and 9 t/ha green leaf yield. Application of FYM @ 6 t/ha + Rhizobium + PSM significantly increased plant height $(32.9 \mathrm{~cm})$, pod weight per plant (11.9), seed index (55.3 g) and yield (1278 $\mathrm{kg} / \mathrm{ha}$ ) Zalate and Padmani (2009).

Sharma (2013) revealed that the growth, development, yield attributes of rice was found to be best when $50 \% \mathrm{~N}$ through farm yard manure and 50\% NPK was applied in rice-wheat cropping system. Moreover Ali et al., (2009) reported that significantly highest grain and straw yield of rice $\left(5.52 \mathrm{t} \mathrm{ha}^{-1}\right.$ and $6.73 \mathrm{t} \mathrm{ha}^{-1}$ respectively) was obtained in $70 \%$ of recommended dose of chemical fertilizers and 3 tones poultry manure $\mathrm{ha}^{-1}$ than $70 \%$ NPKS alone and the control. Moreover Khan et al., (2007) observed the combined fertilizer application of NPK: GM: Zn (soil application) at a rate of $120-90-60 \mathrm{~kg} \mathrm{ha}^{-1}: 10 \mathrm{t} \mathrm{ha}^{-1}: 10 \mathrm{~kg}$ $\mathrm{ha}^{-1}$ gave significantly maximum plant height, number of tillers, number of panicles, number of spikelet's, 1000 grain weight, yield and straw yield of paddy rice as compared to NPK alone and the control (Table 2). Ranjitha et al., (2013) observed that significantly maximum grain and straw yield of rice was recorded with the application of $50 \%$ recommended dose of nitrogen through urea $+50 \%$ recommended dose of nitrogen through vermicompost. It was also noticed that straw yield of rice was 3.7, 15.9 and $20.7 \%$ higher when NPK applied with farm yard manure, vermicompost and poultry manure, respectively as compared to NPK alone (Khursheed et al., 2013). Larijani and Hoseini (2012) also found that more tiller number $(28 \%)$, more panicle $/ \mathrm{m}^{2}(60 \%)$, number of filled grains $/ \mathrm{m}^{2}(20.6 \%)$, spikelet per panicle $(19.6 \%)$ and more grain yield $(30.6 \%)$ with combined use of organic and chemical fertilizer compared with chemical fertilizer alone

Mahmud et al., (2016) showed that application of medium level of chemical fertilizer with $4 \mathrm{t}$ $\mathrm{ha}^{-1}$ vermi-compost gave the maximum yield. It was observed that over dose of NPKS fertilizers from chemical source decreased rice yield. Results also revealed that the highest plant height, effective tillers hill ${ }^{-1}$, flag leaf length, panicle length, filled grains panicle ${ }^{-1}$, 1000-grain weight, grain yield, straw yield and biological yield were obtained from the combination of $4 \mathrm{t} \mathrm{ha}^{-1}$ vermi-compost with $100 \mathrm{~kg} \mathrm{ha}^{-1} \mathrm{~N}, 16 \mathrm{kgha}^{-1} \mathrm{P}, 66 \mathrm{kgha}^{-1} \mathrm{~K}, 12$ $\mathrm{kgha}^{-1} \mathrm{~S}$.It was observed that yield of rice can be increased substantially with the judicious application of organic fertilizer with chemical fertilizer. Sharada and Sujathamma, (2018) revealed that the variety DRR Dhan 39 gave the statistically significant higher grain and straw yield with $50 \%$ organic fertilizers of Vermicompost, Jeevamrutha $5 \%$ and Panchagavya $3 \%$ and $50 \%$ inorganic fertilizer of NPK. Chinnamani et al., (2018) also found that under system of rice intensification combined application of $100 \% \mathrm{RDF}+$ poultry 
manure $\left(3 \mathrm{t} \mathrm{ha}^{-1}\right)+3 \%$ Panchakavya foliar spray at transplanting, panicle initiation and $50 \%$ flowering observed the best integrated nutrient management practice for higher yield and nutrient uptake.

Kumar et al., (2014) observed that the application of organic and inorganic source of nutrient in combination increased the yield attributes (Table 3). Application of $125 \%$ RDF +5 t/ha vermin-compost recorded significantly higher yield attributes viz. number of panicle $/ \mathrm{m}^{2}$, panicle length , panicle and test weight followed by treatment $100 \%$ $\mathrm{RDF}+5 \mathrm{t} / \mathrm{ha}$ vermin-compost. Moreover, other treatments were significantly superior over control. Similar finding were also reported by Ramalakshmi et al., (2012); Alim (2012). The higher yield attributes is might be due to higher levels of inorganic fertilizers have been increases the activity of photosynthesis and enzymes which responsible for transformation of energy, carbohydrates, fat metabolism and respiration of plant. Organic manures acting as slow release source of $\mathrm{N}$ are expected to more closely match with $\mathrm{N}$ and supply of other nutrients with demand of rice crop and this could reduce the $\mathrm{N}$ losses and also improved the nutrient use efficiency particularly of nitrogen (Becker et al., 1994). Saba et al., (2013) further noticed that combination of biofertilizer, nitrogen and phosphorous (500: 120: $90 \mathrm{~kg} \mathrm{ha}^{-1}$ ) exceeded all other treatments including $\mathrm{P}$ and $\mathrm{N}$ alone in number of tillers $\mathrm{m}^{-2}$, number of panicles $\mathrm{m}^{-2}$, number of spikelet's panicles ${ }^{-1}$, percent normal kernels, 1000 -grain weight $(\mathrm{g})$ and paddy yield $\left(\mathrm{t} \mathrm{ha}^{-1}\right)$.

Baishya et al., (2015) reported that the different sources of organic manure and inorganic fertilizers influenced positively the growth and yield of paddy (Table 4). Among the nutrient management practices, crop receiving $2.5 \mathrm{t}$ poultry manure $\mathrm{ha}^{-1}+125 \%$ CDF $\left(75+16.5+31.3 \mathrm{~kg} \mathrm{~N} \mathrm{P}\right.$ and $\left.\mathrm{K} \mathrm{ha}^{-1}\right)$ recorded the taller plants, higher effective tillers, panicle length, grain and straw yield which closely followed by the $2.5 \mathrm{t}$ poultry manure $\mathrm{ha}^{-1}+100 \%$ CDF $(60+13.1+25 \mathrm{~kg}$ $\mathrm{N}, \mathrm{P}$ and $\mathrm{K} \mathrm{ha}^{-1}$ and 5t FYM ha ${ }^{-1}$ along with $125 \% \mathrm{CDF}(75+16.5+31.3 \mathrm{~kg} \mathrm{~N} \mathrm{P}$ and $\mathrm{K}$ $\mathrm{ha}^{-1}$. However, among the organic sources, addition of vermin-compost $\left(1\right.$ tha $\left.^{-1}\right)$ produced better growth and grain yield followed by $2.5 \mathrm{t}$ poultry manures $\mathrm{ha}^{-1}$ and 5t FYM ha ${ }^{-1}$. This might be due to better and timely nutrient availability to the crop from the vermincompost as compared to other sources of organic manure. This is in conformity with the findings of Singh and Kumar (2014). Application of $100 \%$ recommended dose of nitrogen from urea significantly influenced the yield of rice in $1^{\text {st }}$ year of experiment but during the $2^{\text {nd }}$ year of experiment application of $50 \%$ recommended dose of nitrogen from vermicompost and the rest through chemical fertilizer (urea) produced significantly highest grain and straw yield of rice in rice-wheat cropping system (Koushal et al., 2011). Moreover, the mean grain yield of rice for the three years showed that significantly higher rice yields than the other treatments at $4.0 \mathrm{t}$ $\mathrm{ha}^{-1} \mathrm{PM}+30 \mathrm{~kg} \mathrm{Nha}^{-1}$ and $2.0 \mathrm{t} \mathrm{ha}^{-1} \mathrm{PM}+$ 22.5-15-15 kg N: $\mathrm{P}_{2} \mathrm{O}_{5}: \mathrm{K}_{2} \mathrm{O}_{\text {ha }}{ }^{-1}$ (Issaka et al., 2014). Larijani and Hoseini (2012) also found that more tiller number $(28 \%)$, more panicle $/ \mathrm{m}^{2}(60 \%)$, number of filled grains $/ \mathrm{m}^{2}$ $(20.6 \%)$, spikelet per panicle $(19.6 \%)$ and more grain yield $(30.6 \%)$ with combined use of organic and chemical fertilizer compared with chemical fertilizer alone.

Moe et al., (2019) reported that higher tiller numbers were observed in the $\mathrm{CF}_{50} \mathrm{PM}_{50}$ treatment across all growth stages. The maximum tiller number was observed at 40 DAT; 34.73 and 38.22 tillers per hill in the $\mathrm{CF}_{50} \mathrm{PM}_{50}$ plots in 2017 and 2018, respectively (Fig. 1a). Tiller numbers declined after 45 DAT in all treatments. At harvest time, the maximum tiller numbers of 18.2 and 22.5 
tillers per hill were observed in $\mathrm{CF}_{50} \mathrm{PM}_{50}$ plots in 2017 and 2018, respectively. The development of the tiller primordium depends on the $\mathrm{N}, \mathrm{P}$, and $\mathrm{K}$ contents in leaves and sheaths. Tiller number increases linearly with sheath N content (Yoshida, 1981). A high sheath $\mathrm{N}$ content increases the cytokinin content within tiller nodes and enhances the germination of the tiller primordium (Liu et al., 2011). Similarly rice plants accumulated a large amount of DM during the tillering stage in the CF100 treatment in 2017 (Fig. 1b). After that stage, DM production was similar among the $\mathrm{CF}_{100}, \mathrm{CF}_{50} \mathrm{PM}_{50}, \mathrm{CF}_{50} \mathrm{CM}_{50}$, and $\mathrm{CF}_{50} \mathrm{CP}_{50}$ treatments. At harvest, the maximum DM produced was $15.01 \mathrm{t} \mathrm{ha}^{-1}$, from the $\mathrm{CF}_{50} \mathrm{PM}_{50}$ treatment, followed by $14.29 \mathrm{t} \mathrm{ha}^{-1}$ in the $\mathrm{CF}_{100}$ treatment. The amounts of $\mathrm{DM}$ produced in the $\mathrm{CF}_{50} \mathrm{CM}_{50}$ and $\mathrm{CF}_{50} \mathrm{CP}_{50}$ treatments were 12.30 and 11.26 $\mathrm{t} \mathrm{ha}^{-1}$, respectively. The most $\mathrm{DM}$ was produced in $\mathrm{CF}_{50} \mathrm{PM}_{50}$ plots in 2018 even during the early stage. Throughout the crop period, plots treated with organic fertilizers produced DM amounts similar to those from plots treated with $\mathrm{CF}_{100}$. At harvest time, $\mathrm{CF}_{50} \mathrm{PM}_{50}$ plots produced the most DM, 15.49 $\mathrm{t} \mathrm{ha}^{-1}$. $\mathrm{CF}_{50} \mathrm{CM}_{50}$ and $\mathrm{CF}_{50} \mathrm{CP}_{50}$ also produced significantly more DM in 2017 than in 2018. DM production in the $\mathrm{CF}_{50} \mathrm{CM}_{50}$ and $\mathrm{CF}_{50} \mathrm{CP}_{50}$ treatments was not significantly different from that in the $\mathrm{CF}_{100}$ treatment. Plants treated with CF100 produced more DM than plants treated with organic fertilizers. The $\mathrm{CF}$ used is readily soluble and hence can supply nutrients to rice plants within a short time after application (Sarker et al., 2017).

Kumar et al., (2017) revealed that combined application of FYM + BGA produced significantly higher growth parameters, yield attributes and yield of rice over FYM and control (Table 5). Hence, aromatic rice can be grown with $100 \%$ RDF and FYM along with BGA for higher growth and productivity under eastern U. P condition. Devkota et al., (2019) showed that application of half of recommended $\mathrm{N}$ : $\mathrm{P}_{2} \mathrm{O}_{5}: \mathrm{K}_{2} \mathrm{O}$ from the inorganic fertilizer sources along with soil incorporation of $20 \mathrm{~cm}$ crop residue produced significantly higher value for plant height, number of tillers per square meter, panicle length and Grain yield.

Tiwari et al., (2017) observed that the application of $50 \% \mathrm{RDF}+50 \%$ nutrient through FYM recorded highest growth parameter and yield in rice (Table 6). The higher growth and yield of rice may be attributed to good soil health due to the application of farm yard manure with fertilizes; many other scientists have also observed the same phenomenon.

Baghdadi et al., (2018) revealed that the combining chemical fertilizers with chicken manure $(\mathrm{CM})$ in a 50:50 ratio and applying $50 \% \mathrm{NPK}+50 \% \mathrm{CM}+\mathrm{BF}$ produced grain and dry matter (DM) yields that were similar to those produced in the $100 \%$ nitrogen $(\mathrm{N})$, phosphorus $(\mathrm{P})$, potassium $(\mathrm{K})$ treatment. Among the lone fertilizer treatments, the inorganic fertilizer (100\% NPK) treatment produced the highest DM yield and out yielded the $100 \%$ CM treatment. However, when CM was combined with NPK, the resulting DM yield was the same as that resulting from 100\% NPK (13.68 t/ha). Compared with CM applications alone, combinations of NPK and CM applications resulted in increased plant height, crop growth rates (CGRs) and leaf area index (LAI), but the values of these parameters were similar to those resulting from $100 \%$ NPK application.

Iqbal et al., (2019) also found that biomass and $\mathrm{N}$ accumulation increased progressively with improved growth and attained the highest weight at maturity. Biomass and $\mathrm{N}$ accumulation (NA) differed significantly between control and $\mathrm{N}$ embedded treatment (Fig. 2A-D). The differences among 
treatments showed a similar trend for both seasons. Sole urea application $\left(\mathrm{T}_{2}\right)$ resulted in a higher biomass (18.14 $\mathrm{g} \mathrm{hill}^{-1}$ and NA $0.38 \mathrm{~g}$ hill $^{-1}$ ) at the tillering stage across the seasons, while at heading and maturity, there was maximum biomass accumulation (43.32 and $\left.66.22 \mathrm{~g} \mathrm{hill}^{-1}\right)$ and NA (0.43 and $0.67 .56 \mathrm{~g}$ hill $^{-1}$ ), respectively, in $\mathrm{T}_{6}$ across the seasons. In-addition, $\mathrm{T}_{2}$ and $\mathrm{T}_{4}$ were statistically comparable with $\mathrm{T}_{6}$. The lowest biomass and NA were observed in control, followed by $T_{5}$ and $\mathrm{T}_{3}$, during both seasons. Co-applied organic and inorganic fertilizer had significantly increased nitrogen use efficiency (NUE) compared with sole inorganic fertilizer application. Among the treatments, $\mathrm{T}_{6}$ showed higher NUE by $43.5 \%$, followed by T4at $42.8 \%$, across the seasons (Fig. 2E-F). Similarly, $\mathrm{T}_{3}$ and $\mathrm{T}_{5}$ also increased the NUE, and lower NUE was noted in sole urea fertilizer treatment during both seasons. Moe et al., (2017) observed that there was no statistically significant difference in the number of tillers generated using $\mathrm{I}_{100}$ compared with 50\% NPK $\left(\mathrm{I}_{50}\right)$ inorganic fertilizer. However, a larger number of tillers were present in rice plants grown using $\mathrm{I}_{100}$ compared with $0 \%$ NPK $\left(\mathrm{I}_{0}\right)$ fertilizer. The maximum tiller number was produced using $\mathrm{I}_{75} \mathrm{Op}$ in the dry season $\left(19.22 \mathrm{hill}^{-1}\right)$ and $\mathrm{I}_{100} \mathrm{Op}$ in the wet season $\left(17.00 \mathrm{hill}^{-1}\right)$ [Fig.2b].

Singh et al., (2018) stated that the grain and straw yield and harvest index of rice increased with the application of $100 \%$ RDF and more increased when 25 or $50 \%$ nutrients substituted through organic sources i.e. FYM, GM or wheat straw along with 75 or $50 \%$ RDF. The maximum rice grain and straw yield and harvest index were obtained with $50 \%$ $\mathrm{RDF}+50 \% \mathrm{~N}$ as FYM (Table 7) which remained at par with treatments, $50 \% \mathrm{RDF}+50 \% \mathrm{~N}$ as wheat straw and $50 \% \mathrm{RDF}+50 \% \mathrm{~N}$ as GM. The higher yield was achieved through integrated nutrient management because the grain and straw yield is the final product which depends upon the development of yield components such as effective tillers, panicle length, test weight, total and filled grain panicle ${ }^{-1}$. All the yield attributes and yield were higher with the substitution either 25 or $50 \% \mathrm{~N}$ as FYM or green manure or wheat straw in combination with 50 or $75 \%$ RDF due slow release and continuous supply of nutrients in balance quantity throughout the various growth stages enables the rice plants to assimilate sufficient photosynthetic products and thus, increased the dry matter and source capacity resulted in increased of yield attributes and finally yield of grain and straw. Furthermore, substitution of 25 or 50 organic in combination with 5075\% RDF improved physicochemical and biological properties of soil which improved the efficiency in utilization of native as well as applied nutrients at faster rate, which favoured better plant growth and improved the yield components of rice (Pandey et al., 2007). Thus, the application of $50 \%$ RDF along with $50 \% \mathrm{~N}$ either through FYM or green manure or wheat straw may be recommended for getting higher grain yield of rice.

Gangmei and George (2017) observed that the significant and highest grain yield was reported in treatment $T_{11}$, however treatments $\mathrm{T}_{10}, \mathrm{~T}_{9}$ and $\mathrm{T}_{8}$ shows parity with $\mathrm{T}_{11}$. There was $59.47 \%$ increase in grain yield ha ${ }^{-1}$ in $\mathrm{T}_{11}$ over $\mathrm{T}_{12}$. Also addition of 10 tonnes FYM with $100 \mathrm{RDF}\left(\mathrm{T}_{11}\right)$ increases the grain yield by $29.57 \%$ over $100 \mathrm{RDF}\left(\mathrm{T}_{5}\right)$ alone. Further, highest straw yield was reported in treatment $\mathrm{T}_{11}$ which is at par with $\mathrm{T}_{10}, \mathrm{~T}_{8}, \mathrm{~T}_{9}$ and $\mathrm{T}_{7}$. The lowest straw yield $\left(\mathrm{kg} \mathrm{ha}^{-1}\right)$ was observed in $\mathrm{T}_{12}$ (No manure and fertilizer) which is also at par with $T_{1}, T_{2}$ and $T_{3}$. The maximum yield attained in treatments where integrated use of FYM and inorganic fertilizers were due to the fact that inorganic fertilizers releases nutrients for the plants instantly and in readily available forms for the plants during its growth, 
development and reproductive phases where the nutrient demand is at its peak. Micro nutrients supplied by the FYM enhanced the macro nutrients uptake and also slowly release during the whole crop period. Slow-acting bulky organic manures like compost and farm yard manure are hard to decompose (because of wider $\mathrm{C}$ : $\mathrm{N}$ ratio) and making nitrogen available at later stages (Khan et al., 2001). Organic fertilizer with inorganic fertilizer increased the fertilizer use efficiency and improved the physical and chemical properties of soil and it would be a reason towards increased yield (Banik et al., 2006). Increasing the levels of nutrients enhances the nutrient availability thereby increases yield attributes such as number of effective tillers hill-1 number of spikelet's panicle-1, percentage of filled grains and test weight.

\section{Effect of integrated nutrient management on soil health}

\section{Why integrated soil fertility management?}

Sustaining soil fertility and increasing productivity using organic resources alone would be required large amount of organic fertilizer to maintain soil fertility levels in each and every field. However, the opposite strategy, the use of inorganic fertilizers alone may lead to high crop yields in the short period of time. But it affects soil structure which leads to decline of organic matter and environmental pollution (Ali et al., 2009). The problems associated with the single approach application of organic or inorganic fertilizers have made a combination of organic and inorganic fertilizers a realistic option in improving soil fertility and productivity. So the best ways for soil fertility is, therefore, integration of both inorganic and organic fertilizers to increases soil productivity as well as soil fertility (Nyalemegbe et al., 2009) by less expensive ways (Nyalemegbe et al., 2009; Mungai et al., 2009) and decreases the damage that can be induced by chemical fertilizers (Han et al., 2016). Brar et al., (2015) showed that integrated use of inorganic fertilizer along with organic fertilizer $(100 \%$ $\mathrm{NPK}+\mathrm{FYM}$ ) improved soil physical conditions such as CEC and $\mathrm{pH}$ resulted in higher yields. According to Han et al., (2016) the NPK fertilizer treatment leads to soil acidification, whereas organic manure + NPK treatments significantly increased soil $\mathrm{pH}$. Similar type findings was reported by (Walia et al., 2010) also found that the incorporated nutrient management system results in rising organic carbon content, available nitrogen, phosphorus and potassium increasing from $0.390 \%$ to $0.543 \%, 171.7$ to $219.3 \mathrm{kgha}^{-1}$ and 20.5 to $43.3 \mathrm{kgha}^{-1}$ respectively.

Tharmaraj et al., (2011) reported that soil application of vermicompost and spray of vermiwash improved physical (water holding capacity, porosity and moisture content), chemical properties ( $\mathrm{pH}$ and EC) as well as soil fertility (N, P, K, Ca and Mg over control and its individual application. Effect of integrated nutrient management on soil fertility management on soil fertility were studied by Naidu et al. (2009) and results revealed that highest status of major and micronutrients in soil in the treatment, $50 \%$ $\mathrm{RDN}+50 \% \mathrm{~N}$ through $\mathrm{FYM}+\mathrm{BF}+$ Panchagavya@3\% foliar spray similar results were obtained by Ansari and Kumar (2010) i.e. The significantly higher content of organic $\mathrm{C}$ in the treatment of vermiwash +vermicompost followed by only vermicompost and only cowdung (100 g/plant). However, higher content of N, P, K, $\mathrm{Ca}, \mathrm{Mg}, \mathrm{Fe}, \mathrm{Mn}, \mathrm{Zn}$ and $\mathrm{Cu}$ were observed in the chemical fertilizer treatment followed by treatments of vermiwash + vermicompost

Dubey et al., (2014) reported that the improvement in organic carbon and nitrogen contents as well as maintenance of phosphorus and potash contents was noticed over their 
initial status under $100 \%$ organic nutrient management with all cropping systems till the completion of fourth crop cycle. The organic carbon and nitrogen content were almost maintained and phosphorus and potash contents showed a little declining trend over their initial status with $100 \%$ inorganic nutrient management. Baishya et al., (2015) concluded that the crop receiving $2.5 \mathrm{t}$ poultry manure $\mathrm{ha}^{-1}$ along with $75 \mathrm{~kg} \mathrm{~N}+16.5$ $\mathrm{kgP}+31.3 \mathrm{~kg} \mathrm{~K} \mathrm{ha}^{-1}$ recorded significant improvement (Table 8) in soil organic carbon, nitrogen, phosphorus and potassium status of soil after harvest of the crop. Kumar and Haefele (2013) reported that application of nitrogen at $90 \mathrm{~kg}$ level as 50\% through Rice straw compost $+50 \%$ nitrogen as poultry manure registered higher available $\mathrm{N}, \mathrm{P}$ and $\mathrm{K}$ contents of soil during different growth stages as compared to the other treatment combinations. Naresh et al., (2015) reported that SOC concentration in surface soil $(0-15$ $\mathrm{cm})$ was not significantly or slightly increased by the $15 \mathrm{yr}$ of fertilizer treatments $(\mathrm{N})$, but they were sharply increased by the manure and straw amendment (FYM, and FYM+GM/SPM). Thus, returning crop residue to the soil or adding farmyard manure on the soil surface is crucial to improving the SOC level. The large scale implementation of the straw or manure plus inorganic fertilizer amendments will help to enhance the capacity of carbon sequestration and promote food security in the region.

Mallikarjun and Maity (2018) reported that the highest bacterial count $\left(39.4 \times 10^{5} \mathrm{CFU} \mathrm{g}^{-1}\right.$

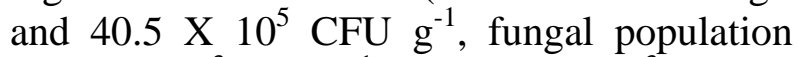
$\left(14.06 \times 10^{3} \mathrm{CFU} \mathrm{g}^{-1}\right.$ and $15.08 \times 10^{3} \mathrm{CFU} \mathrm{g}^{-}$ ${ }^{1}$,actinomycetes population $\left(30.2 \times 10^{2} \mathrm{CFU}\right.$ $\mathrm{g}^{-1}$ and $32.8 \times 10^{2} \mathrm{CFU} \mathrm{g}^{-1}$ in the year 2015 and 2016, respectively) was observed with the application of $50 \% \mathrm{~N}$ as chemical fertilizer with 25\% FYM along with Azollain a dual cropping, were statistically at par with the application of $75 \% \mathrm{~N}$ as chemical fertilizer along with Azolla. However, the application of organics along with chemical fertilizers registered a significant increase in bacterial, fungal and actinomycetes population over control. Kumar et al., (2005) and Kumari et al., (2017) also reported an increase in bacterial count with application of different organic $\mathrm{N}$ sources compared to control.

Integrated nutrient management (INM) or integrated nutrient supply (INS) help to achieve efficient use of synthetic fertilizers integrated with organic sources of nutrients (Mahajan et al., 2008). INM is developed with an understanding of the interactions among crops, soils, and climate, which advocates the integration of inorganic and organic sources of nutrients. This approach is based on the maintenance of plant nutrition supply to attain a certain level of crop production by enhancing the benefits from all potential sources of plant nutrition in a cohesive manner, applicable to each cropping pattern and farming scenario (Mahajan and Sharma, 2005). The inclusion of organic manures regulates the uptake of nutrients, positively affecting production, improving soil quality (physical, chemical, and biological), and producing a synergistic effect on crops (Yadav and Kumar, 2000). INM integrates traditional and recent practices of nutrient management into an environmentally sound and costeffective ideal farming system that uses remunerations from all probable sources of nutrition (organic, inorganic, and biological) in a careful, effective, and combined way (Wu and $\mathrm{Ma}, 2015)$. It optimizes the balance between input sources and outputs with the goal of coordinating the nutritional demand of the crop and its discharge in its surroundings (Fig. 4).

The integrated application of organic and inorganic fertilizers for 29 years reduced soil reactions by $0.22 \%$ over the application of inorganic fertilizers alone (Kumar et al., 
2017).The effects of INM on nutrient dynamics were recorded, and it was concluded that combining FYM with inorganic fertilizers could maintain SOC and available $\mathrm{N}$ and Pat either equal to or greater than the initial soil nutrient levels, thus maintaining soil fertility even under continuous cultivation (Chaudhary et al., 2017). Incorporation of rice straw with green manure along with inorganic fertilizers increased Av. P by $12.7 \%$ and Av. K by $14.3 \%$, as compared to treatments in which only inorganic sources of nutrients were applied (Kharub et al., 2004). Sesbania greenmanuring in rice, integrated with inorganic fertilizers, increased the available $\mathrm{N}$ from 5.8 to $22.0 \mathrm{~kg} \mathrm{ha}^{-1}$, Av. P from 1.4 to $3.8 \mathrm{~kg} \mathrm{ha}^{-1}$, and Av. K from 2.2 to $17.9 \mathrm{~kg} \mathrm{ha}^{-1}$ (Paikaray et al., 2002) (Table 9).

Liu et al., (2014), in agricultural soils under $40 \mathrm{t} \mathrm{ha}^{-1}$ biochar, soil water stable aggregate (>0.25 mm) in the $0-15 \mathrm{~cm}$ soil layer had a remarkable increase respect to other treatments, especially the macro-aggregate with particle size larger than $>2 \mathrm{~mm}$, suggesting that biochar incorporation into soil improves soil structure (Fig 5b). Lucas et al., (2014) demonstrated that organic amendments containing high amount of bioavailable $\mathrm{C}$ derived from cellulose, can promote fungal proliferation and improve soil structure through stabilization of soil aggregates, suggesting a use of organic amendments to manipulate soil microbial community structure and to promote aggregation in soils. The application of organic amendments in the form of compost is an effective tool to recover soil organic C stock (Zhang et al., 2015). Organic amendments, once added to the soil, favour the growth and diversity of microbial communities, highlighting a strong correlation between soil biological fertility and soil organic C content (Chakraborty et al., 2011).Bonanomi et al., (2011a) who compared the biological characteristics of soils collected from different agricultural farms in a multidisciplinary approach. They found a drastic reduction of soil microbial biomass, fungal mycelium and all enzymatic activities in soils having small organic $\mathrm{C}$ content and under intensive agriculture without use of organic amendments.

The use of compost can affect soil microbial diversity, as reported by Zaccardelli et al., (2013a) who showed a clear positive effect on the number of spore-forming bacteria, with an increase directly correlated with the dose of compost. Also in stressed soil, with high saline content, the use of compost can determine an improvement of biological fertility (Lakhdar et al., 2009). Ouni et al., (2013) investigated the effects of composts, produced by MSW and palm wastes, at several doses $\left(0,50,100\right.$, and $\left.150 \mathrm{t} \mathrm{ha}^{-1}\right)$ on saline soil. They observed an increase of soil organic matter and consequently an improving of microbial biomass and several enzyme activities but the results were different in presence of the highest dose of compost (150 t $\mathrm{ha}^{-1}$ ), where a reduction of some activities was registered. This behaviour could be likely attributed to the potential toxic effect of the trace elements present in this particular compost (Crecchio et al., 2004).

Ding et al., (2016) reported that manures and composts contain pathogens, heavy metals, and pharmaceuticals, which may cause longterm contamination of farmland. Moreover, manures and composts have the potential to lead to ammonia and methane releases, which can aggravate global warming and serious groundwater and stream nutrient pollution. Being a renewable resource and due to its economic and environmental benefits (Fig. $6 a)$, biocharis a promising resource for soil's fertility management. Furthermore, biochar loaded with ammonium, nitrate, and phosphate could be also proposed to be a slow-release fertilizer to enhance soil fertility (Xu et al., 2014; Schmidt et al., 2015; 
Kammann et al., 2015).In order to better understand the connections between biochar and soil, four following aspects are included in this paper (Fig. 6b): (i) biochar as a source of nutrients; (ii) adsorption and desorption of nutrients on biochar; (iii) the influence of biochar on properties of soils; and (iv) the effects of biochar on biota in soil. Biochar has high total porosity and it could both retain water in small pores and thus increase water holding capacity and assist water to infiltrate from the ground surface to the topsoil through the larger pores after heavy rain (Asai et al., 2009). Peake et al., (2014) indicated that biochar application could increase available water capacity by over $22 \%$. Nelissen et al., (2015) demonstrated that biochar application could increase available water capacity from 0.12 to $0.13 \mathrm{~m}^{3} \mathrm{~m}^{-3}$. Laird et al., (2010) indicated that the biochar treatments significantly increased cation exchange capacity by 4 to $30 \%$ and relative to the controls.

Wang et al., (2014) indicated that the amounts of the extractable $\mathrm{K}, \mathrm{Ca}, \mathrm{Na}$, and $\mathrm{Mg}$ approximately increased by ranging from 60 to $670 \%$ after biochar addition. For example, the $\mathrm{K}$ content of soil increased from 42 to 324 $\mathrm{mg} \mathrm{kg}$ (Wang et al., 2014). In addition, biochar treatment could increase base saturation percentage from 6.4 to $26 \%$ and saturated hydraulic conductivity from 16.7 to $33.1 \mathrm{~cm} \mathrm{~h}^{-1}$, decrease soil erosion rate from 1458 to $532 \mathrm{~g} \mathrm{~m}^{-2} \mathrm{~h}^{-1}$ (Jien and Wang 2013), and increase total $\mathrm{C}$ from 2.27 to $2.78 \%$ and total $\mathrm{N}$ from 0.24 to $0.25 \%$ and available $\mathrm{P}$ from 15.7 to $15.8 \mathrm{mg} \mathrm{kg}^{-1}$ (Jones et al., 2012). These improvements in soil chemical properties could increase soil fertility by increasing the nutrient contents and availability. Deenik et al., (2010) and Spokas et al., (2011) indicated that biochar with high volatile matter content, which produced at higher temperature, contributed to $\mathrm{N}$ immobilization and microbial activity reduction which could inhibit plant growth.
The possible improvements of soil's properties and fertility after biochar application were shown in Fig. 6c. On the one hand, the properties of soils, containing physical, chemical, and biological properties, could be improved after biochar treatment. Moreover, the improvement of soils properties is highly related to the specific physicochemical properties of biochar, such as high surface area, amount of functional groups, and the content of liming. For example, soil's cation exchange capacity may increase with the increase of carboxylic groups and surface area. The well-developed pore structure may not only enhance the capacity of water retention but also provide a shelter for soil's micro-organisms, thus nutrient retention and cycling could be improved. The content of liming contained in biochar may increase soil's $\mathrm{pH}$ values. On the other hand, biochar could increase plant nutrient availability in soils by releasing nutrients, retaining nutrients, reducing nutrients leaching, and mitigating gaseous $\mathrm{N}$ losses. Therefore, biochar has great potential in the improvement of soil fertility.

\section{Effect of INM on grain quality of rice}

Ebaidand El-Hissewy, (2000) indicated that increasing nitrogen fertilizer levels from 0 up to $165 \mathrm{~kg} \mathrm{~N}^{-1}$ significantly increased hulling percentage in Sakha 101 rice cultivar. The highest values of hulling percentage were observed at $165 \mathrm{~kg} \mathrm{~N} \mathrm{ha}^{-1}$, followed by $110 \mathrm{~kg}$ $\mathrm{N} \mathrm{ha}^{-1}$. This increase could be attributed due to the application of nitrogen increased grainfilling rate consequently decreased the hull thickness. These findings are in close agreement with those of reported by Metwally et al., (2011b).

Sravan and Singh (2019) stated grain protein content and yield of basmati rice differed significantly due to varied fertility levels and bio-inoculants showed higher protein content because of more $\mathrm{N}$ content in grain. Similar 
differences in protein content of cultivars were also noted (Ghosh et al., 2004; Chandel et al., 2010; Singh and Sravan, 2017). Higher protein content and yield with use of bio-inoculants might be due to continuous $\mathrm{N}$ supply and its efficient translocation to grain; greater nitrogen content in grain customized the proportion of grain constituents (Yadav and Singh, 2013). Integrated nutrient management recorded maximum values for quality characters, application of entire nutrients as inorganic source exhibited $4.2 \%$ lower milling than use of organics in combination. FYM supplied macro and micro nutrients in optimum quantities, resulted enhanced quality. Quality parameters improved with combined use of organic and inorganic nutrient sources (Dixit and Gupta, 2000), incorporation of FYM significantly increased the hulling per cent in rice (Prakash et al., 2002). Maximum improvement in hulling, milling and head rice recovery occurred by BGA + Azospirillum (B3) was due to enhanced availability of nitrogen for longer duration. Differences in hulling, milling and head rice recovery with bio-inoculants were also reported (Quyen and Sharma, 2003; Davari and Sharma, 2010).

Gharieb et al., (2017) reported that the combination of organic and inorganic sources of nutrients is necessary for sustainable agriculture that can ensure quality crop. The interaction between nitrogen and compost had a significant effect on hulling percentage in 2013. The highest values of HP were recorded with the combination of $165 \mathrm{~kg} \mathrm{~N}$ and 3.5 or 7 $\mathrm{t}$ compost $\mathrm{ha}^{-1}$. There were no significant deference between 110 and $165 \mathrm{~kg} \mathrm{~N}$ combined with $7 \mathrm{t}$ compost $\mathrm{ha}^{-1}$. Moreover, the lowest values of HP were obtained under zero nitrogen and zero compost combination (Table 10). Saha et al., (2007) reported that inorganic sources of nutrients influenced more than organic sources on crop growth and quality. Broken rice percentage was significantly controlled by the application of nitrogen in the two seasons. Increasing nitrogen fertilizer from 0 to $165 \mathrm{~kg} \mathrm{~N} \mathrm{ha}^{-1}$ decreased significantly broken rice percentage. Moreover, the highest values of broken rice percentage recorded when nitrogen was not applied. This result was also documented by Srivastava et al., (2009) and Ebaid and El-Hissewy (2000). Compost rate influenced significantly on broken rice percentage in both seasons and it decreased with increasing compost. The lowest broken rice percentage was obtained at $7 \mathrm{t}$ compost $\mathrm{ha}^{-1}$, followed by (3 $\left.\mathrm{tha}^{-1}\right)$. Pandey et al., (1999) found higher head rice per cent with the application of of $10 \mathrm{t}$ compost ha $\mathrm{H}^{-1}$.

Saha et al., (2007) reported that the protein content in grains was the highest, $8.98 \%$, in the inorganic treatment (100:60:40 kg N, P, K $\mathrm{ha}^{-1}$ ) and lowest, $7.55 \%$, in the control. Among organic treatments, farmyard manure at $10 \mathrm{Mg} \mathrm{ha}^{-1}$ contributed the least in terms of the protein content of the rice (7.78\%). Significantly higher iron content, of $52.2 \mu \mathrm{g}$ $\mathrm{g}^{-1}$, was recorded with organic fertilization than inorganic fertilization $\left(42.1 \mu \mathrm{g} \mathrm{Fe} \mathrm{g}^{-1}\right)$. However, inorganic fertilization was superior in terms of copper content, of $4.1 \mu \mathrm{g} \mathrm{Fe} \mathrm{g}^{-1}$, compared with organic treatments: $3.1-4.0 \mu \mathrm{g}$ $\mathrm{Fe}^{-1}$. Quality attributes indicated that cooked kernel length was positively correlated with the kernel elongation ratio. Winter weed compost provided comparative benefits for rice yield (3.87 $\mathrm{Mg} \mathrm{ha}^{-1}$ ) and quality in terms of protein $(8.42 \%)$, iron $\left(48.31 \mu \mathrm{g} \mathrm{g}^{-1}\right)$ and head rice recovery $(49.39 \%)$ compared with other sources of nutrients.

Kumar (2010) revealed that kernel length and kernel breadth before and after cooking were higher in treatments getting higher proportion of inorganic-N. Hulling and milling percentage and shape index before and after cooking were not affected markedly. Head rice recovery was higher in the treatment receiving higher proportion of organic-N. 
Benefit of organic manure comes through changes in soil properties for which a minimum of four to five years application would be essential (Table 11). Similar findings were reported by Munda, (2009). Imade et al., (2017) found protein content and protein yield were increased significantly due to application of general RDF (RDF + FYM @ 10 t/ha) closely followed by 75\% RDN through chemical fertilizer $+25 \%$ RDN through vermin-compost. The increase in protein content of rice grain due to more quantity of nitrogen content in grain, improved metabolic activities in the plant (Subbiah and Kumarswamy, 2000) and the variation in protein yield was observed because of nitrogen uptake associated with its levels of supply as well as plant potential to absorb and utilize. Similar results were reported earlier by Gaud, (2004). Gharieb et al., (2017) observed that there was a significant effect on HP in the two seasons due to the interaction effect of nitrogen levels and ascobiens praying frequencies. The highest values of HP were obtained at three times ascobien spraying along with $165 \mathrm{~kg} \mathrm{~N}^{-1}{ }^{-1}$ in the first season. While, there were no significant differences on HP among ascobien treatments at $165 \mathrm{~kg} \mathrm{~N} \mathrm{ha}^{-1}$ in 2013. Whereas, the lowest values of HP were detected without nitrogen fertilizer at all ascobien treatments. Sharada and Sujathamma, (2018) reported that the quality parameters of straw such as Ash content (Mineral) was observed higher in $\mathrm{T}_{8}$ $(20.65 \%)$ and lowest in $\mathrm{T}_{5}(18.16 \%)$, Crude protein (CP) higher was recorded in control 2 $(5.62 \%)$ and lowest in $\mathrm{T}_{2}(4.17 \%)$, neutral detergent fiber (NDF) higher in $\mathrm{T}_{10}(69.43 \%)$ and lowest in T3 $(65.08 \%)$, acid detergent fiber (ADF) higher in $\mathrm{T}_{8}(52.03 \%)$ and lowest in $\mathrm{T}_{6}(48.66 \%)$. crude fiber (CF) higher in $\mathrm{T}_{8}$ $(44.44 \%)$ and lowest in $\mathrm{T}_{6}(40.39 \%)$, acid detergent lignin (ADL) higher in $\mathrm{T}_{5}(4.55 \%)$ and lowest in $\mathrm{T}_{3}(3.29 \%)$. ADF, CF, ADL were statistically significant at $\mathrm{P}<0.008$ and $\mathrm{P}<0.0001$, respectively. Esfahani et al., (2018) reported that the highest amount of gel consistency for cv.Tarom Hashemi was observed with 100 of NPK and 75\% of recommended nitrogen and manure consumption. The maximum amylose content for cv. Tarom Mahalli was produced with $100 \%$ NPK recommended and manure consumption.

Aulakh et al., (2016) reported that green manuring alone $\left(\mathrm{T}_{2}\right)$ and different combinations of green manuring, FYM and chemical fertilizer $\left(T_{3}, T_{4}, T_{6}, T_{7}\right.$ and $\left.T_{8}\right)$ had statistically similar brown and milled-rice recoveries as that with recommended nitrogen $\left(\mathrm{T}_{1}\right)$ (Table 12). Application of FYM alone $\left(\mathrm{T}_{5}\right)$ recorded significantly lower brown and milled rice recoveries than the recommended nitrogen $\left(\mathrm{T}_{1}\right)$. Head-rice recovery with green manuring $\left(\mathrm{T}_{2}\right)$ and different nutrient combinations $\left(T_{3}, T_{4}\right.$ and $\left.T_{6}\right)$ was statistically at par with that of recommended nitrogen $\left(\mathrm{T}_{1}\right)$. The FYM when supplemented with50\% RN $\left(\mathrm{T}_{7}\right)$ or green manuring supplemented with FYM $\left(T_{8}\right)$ had significantly higher head-rice recovery than that of RN, whereas FYM alone $\left(\mathrm{T}_{5}\right)$ had significantly lower head rice recovery than that of RN $\left(\mathrm{T}_{1}\right)$. The different nitrogen sources did not differ significantly in respect of minimum cooking time, water-absorption ratio and cooking coefficient. Elongation ratio of grains with different nutrient sources was statistically at par with recommended nitrogen. However, the highest elongation ratio was ob-served in FYM $+50 \% \mathrm{RN}\left(\mathrm{T}_{7}\right)$ and it was significantly more than $\mathrm{GM}+50 \%$ $\mathrm{RN}\left(\mathrm{T}_{4}\right)$ and $\mathrm{FYM}+25 \% \mathrm{RN}\left(\mathrm{T}_{6}\right)$. Grain protein content with green manuring $\left(\mathrm{T}_{2}\right)$ was statistically similar to that of $\mathrm{RN}\left(\mathrm{T}_{1}\right)$. The grain protein content was significantly higher by 3.9 and $2.3 \%$ than the RN when FYM was supplemented with $50 \% \mathrm{RN}\left(\mathrm{T}_{7}\right)$ and green manuring $\left(\mathrm{T}_{8}\right)$, respectively. Significantly lower grain protein content than that of $\mathrm{RN}$ was observed with FYM $\left(\mathrm{T}_{5}\right)$ and FYM + 
$25 \% \mathrm{RN}\left(\mathrm{T}_{6}\right)$. The higher protein content and increased elongation ratio with organic manures might be owing to uninterrupted availability of $\mathrm{N}$ coupled with increased absorption and assimilation by plants (Rao et al., 2006).

Table.1 Effect of different treatments on growth and yield of paddy [Source: Virdia and Mehta, 2008]

\begin{tabular}{|l|c|c|c|c|c|}
\hline Treatments & $\begin{array}{c}\text { Plant } \\
\text { Height } \\
(\mathbf{c m})\end{array}$ & $\begin{array}{c}\text { Effective } \\
\text { tiller } \\
\left(\mathbf{m}^{-2}\right)\end{array}$ & $\begin{array}{c}\text { Panicle } \\
\text { length } \\
(\mathbf{c m})\end{array}$ & \multicolumn{2}{|c|}{ Yield (t/ha) } \\
\cline { 4 - 7 } & & & & $\begin{array}{c}\text { Gr } \\
\text { ain }\end{array}$ & $\begin{array}{c}\text { Str } \\
\text { aw }\end{array}$ \\
\hline Pressmud @ 5t/ha + RDF(80:30:0) & 100 & 329 & 23.7 & 5.0 & $\begin{array}{c}\mathbf{5 . 6 9} \\
\mathbf{5}\end{array}$ \\
\hline Pressmud @ 10t/ha + RDF & 100 & 326 & 23.4 & 5.1 & $\mathbf{5 . 7 4}$ \\
& & & & 02 & $\mathbf{9}$ \\
\hline Pressmud@ 15 t/ha+ RDF & 100 & 331 & 23.6 & 5.2 & $\mathbf{5 . 8 3}$ \\
& & & & 14 & $\mathbf{8}$ \\
\hline Pressmud @ 20t/ha+RDF & 100 & 330 & 23.8 & 5.3 & $\mathbf{5 . 9 5}$ \\
& & & & 58 & $\mathbf{2}$ \\
\hline Farm yard manure (FYM) @ +10t/ha & 101 & 327 & 23.8 & 5.2 & $\mathbf{5 . 7 8}$ \\
RDF & & & & 46 & $\mathbf{7}$ \\
\hline RDF alone. & 99 & 327 & 23.3 & 5.0 & $\mathbf{5 . 5 9}$ \\
\hline CD(P=0.05) & & & & 69 & $\mathbf{7}$ \\
\hline
\end{tabular}

Table.2 Effect of organic and inorganic fertilizers on different growth and yield parameters of rice [Source: Khan et al., 2007]

\begin{tabular}{|c|c|c|c|c|c|c|c|}
\hline Treatment & $\begin{array}{l}\text { Plant } \\
\text { Height } \\
\text { (cm) }\end{array}$ & $\begin{array}{l}\text { Tillers } \\
\mathrm{m}^{-2}\end{array}$ & $\begin{array}{l}\text { Panicles } \\
\mathrm{m}^{-2}\end{array}$ & $\begin{array}{l}\text { Spikelet } \\
\text { Panicle }^{-1}\end{array}$ & $\begin{array}{l}1000 \\
\text { paddy } \\
\text { Wt.(g) }\end{array}$ & $\begin{array}{l}\text { Paddy } \\
\text { yield } \\
\text { t.ha- }{ }^{-1}\end{array}$ & $\begin{array}{l}\text { Straw } \\
\text { yield } \\
\text { t.ha }{ }^{-1}\end{array}$ \\
\hline Control & $68.67^{\mathrm{e}}$ & $181.7^{\mathrm{e}}$ & $177.3^{\mathrm{e}}$ & $97.7^{\mathrm{e}}$ & $18.17^{d}$ & $4.70^{\mathrm{d}}$ & $8.82^{d}$ \\
\hline NPK alone & $76.30^{\mathrm{d}}$ & $272.7^{\mathrm{d}}$ & $268.7^{\mathrm{d}}$ & $110.8^{\mathrm{d}}$ & $19.90^{\text {cd }}$ & $5.76^{\mathrm{c}}$ & $11.13^{\mathrm{bc}}$ \\
\hline $\mathrm{NPK}+\mathrm{FYM}$ & $88.73^{\mathrm{abc}}$ & $283.0^{\text {cd }}$ & $279.3^{c}$ & $116.8^{\text {bcd }}$ & $22.33^{\mathrm{abc}}$ & $6.64^{\mathrm{b}}$ & $11.20^{\mathrm{bc}}$ \\
\hline $\mathrm{NPK}+\mathrm{GM}$ & $90.53^{\mathrm{abc}}$ & $294.0^{b c}$ & $289.3^{\mathrm{b}}$ & $116.9^{\text {bcd }}$ & $21.83^{\mathrm{abc}}$ & $6.41^{\mathrm{b}}$ & $11.30^{\mathrm{bc}}$ \\
\hline $\mathrm{NPK}+\mathrm{Zn}(\mathrm{SA})$ & $85.93^{\mathrm{bc}}$ & $275.0^{\mathrm{d}}$ & $271.0^{\text {cd }}$ & $116.0^{\text {bcd }}$ & $20.17^{\mathrm{bcd}}$ & $6.51^{\mathrm{b}}$ & $11.03^{\mathrm{bc}}$ \\
\hline $\mathrm{NPK}+\mathrm{FYM}+\mathrm{Zn}(\mathrm{SA})$ & $89.27^{\mathrm{abc}}$ & $306.0^{\mathrm{ab}}$ & $301.3^{\mathrm{a}}$ & $116.2^{\text {bcd }}$ & $22.83^{\mathrm{abc}}$ & $7.26^{\mathrm{a}}$ & $13.3^{\mathrm{a}}$ \\
\hline $\mathrm{NPK}+\mathrm{GM}+\mathrm{Zn}(\mathrm{SA})$ & $93.53^{\mathrm{a}}$ & $315.0^{\mathrm{a}}$ & $309.3^{\mathrm{a}}$ & $136.5^{\mathrm{a}}$ & $23.50^{\mathrm{a}}$ & $7.32^{\mathrm{a}}$ & $13.93^{\mathrm{a}}$ \\
\hline $\mathrm{NPK}+\mathrm{Zn}(\mathrm{RD})$ & $85.00^{c}$ & $284.7^{\mathrm{cd}}$ & $268.3^{\mathrm{d}}$ & $112.1^{\mathrm{cd}}$ & $20.90^{\text {bcd }}$ & $6.30^{\mathrm{b}}$ & $10.6^{\mathrm{c}}$ \\
\hline $\mathrm{NPK}+\mathrm{FYM}+\mathrm{Zn}(\mathrm{RD})$ & $89.4^{\mathrm{abc}}$ & $306.3^{\mathrm{ab}}$ & $301.3^{\mathrm{a}}$ & $121.9^{\mathrm{bc}}$ & $22.83^{\mathrm{abc}}$ & $7.24^{\mathrm{a}}$ & $13.2^{\mathrm{a}}$ \\
\hline $\mathrm{NPK}+\mathrm{GM}+\mathrm{Zn}(\mathrm{RD})$ & $92.67^{\mathrm{ab}}$ & $305.3^{\mathrm{ab}}$ & $307.0^{\mathrm{a}}$ & $125.9^{\mathrm{b}}$ & $23.17^{\mathrm{ab}}$ & $7.25^{\mathrm{a}}$ & $13.2^{\mathrm{a}}$ \\
\hline LSD 0.05 & 7.577 & 13.53 & 9.109 & 10.47 & 3.029 & 0.3639 & 1.625 \\
\hline
\end{tabular}

Values followed by the same letter(s) in each column are not significantly different at $5 \%$ level of probability. Note : Rate of NPK=120-90-60 kg ha-1,FYM=10 tha-1, GM=10 tha $a^{-1}, \mathrm{Zn}(\mathrm{SA})=10 \mathrm{~kg} \mathrm{ha} a^{-1}$ in the form of ZnSO4 fertilizer, $\mathrm{Zn}(R D)=1.0 \%$ in $\mathrm{ZnSO}^{-1}(A . R)$ solution and dipping for 5 minutes. Where NPK:Nitrogen, Phosphorus and Potassium respectively; FYM:Farm Yard Manure, GM:GreenManure; Zn:Zink; SA: Soil Application; RD:Root Dipping; 
Table.3 Effect of organic and inorganic sources of nutrient on yield attributes, yield and protein content of rice (Source: Kumar et al., 2014)

\begin{tabular}{|c|c|c|c|c|c|c|c|}
\hline Treatment & $\begin{array}{c}\text { Panicles/m } \\
2 \text { (No.) }\end{array}$ & $\begin{array}{c}\text { Panicle } \\
\text { (cm) } \\
\text { length }\end{array}$ & $\begin{array}{l}\text { Panicle } \\
\text { s wt. (g) }\end{array}$ & $\begin{array}{c}1000 \\
\text { grain wt. } \\
\text { (g) }\end{array}$ & $\begin{array}{c}\text { Grain } \\
\text { yield(t/ } \\
\text { ha) }\end{array}$ & $\begin{array}{c}\text { Straw } \\
\text { yield } \\
(\mathrm{t} / \mathrm{ha})\end{array}$ & $\begin{array}{l}\text { Protein } \\
(\%) \\
\text { content }\end{array}$ \\
\hline Control & 211.8 & 23.2 & 3.1 & 18.6 & 4.03 & 6.23 & 7.3 \\
\hline $75 \%$ RDF & 215.0 & 23.3 & 3.2 & 19.0 & 4.23 & 6.6 & 7.61 \\
\hline $100 \%$ RDF & 220.6 & 25.5 & 3.2 & 19.2 & 4.38 & 7.02 & 7.77 \\
\hline $125 \%$ RDF & 223.0 & 25.6 & 3.3 & 20.1 & 4.56 & 7.49 & 7.87 \\
\hline 2.5 t/ha vermicompost & 217.3 & 24.9 & 3.2 & 19.3 & 4.37 & 6.76 & 7.68 \\
\hline $5 \mathrm{t} /$ ha vermicompost & 219.0 & 25.0 & 3.3 & 20 & 4.47 & 7.33 & 7.93 \\
\hline $\begin{array}{l}75 \% \mathrm{RDF}+2.5 \mathrm{t} / \mathrm{ha} \\
\text { vermicompost }\end{array}$ & 222.8 & 26.3 & 3.2 & 20.2 & 4.75 & 7.72 & 8.28 \\
\hline $\begin{array}{l}100 \% \mathrm{RDF}+2.5 \mathrm{t} / \mathrm{ha} \\
\text { vermicompost }\end{array}$ & 223.1 & 26.8 & 3.3 & 20.3 & 4.79 & 7.78 & 8.39 \\
\hline $\begin{array}{l}125 \% \mathrm{RDF}+2.5 \mathrm{t} / \mathrm{ha} \\
\text { vermicompost }\end{array}$ & 237.4 & 27.5 & 3.4 & 20.4 & 4.84 & 7.78 & 8.56 \\
\hline $\begin{array}{l}75 \% \mathrm{RDF}+5 \mathrm{t} / \mathrm{ha} \\
\text { vermicompost }\end{array}$ & 228.3 & 27.2 & 3.3 & 20.4 & 4.94 & 8.07 & 8.5 \\
\hline $\begin{array}{l}100 \% \mathrm{RDF}+5 \mathrm{t} / \mathrm{ha} \\
\text { vermicompost }\end{array}$ & 254.3 & 28.6 & 3.5 & 20.5 & 5.14 & 8.31 & 8.6 \\
\hline $\begin{array}{l}125 \% \mathrm{RDF}+5 \mathrm{t} / \text { ha } \\
\text { vermicompost }\end{array}$ & 255.5 & 28.6 & 3.6 & 21 & 5.28 & 8.54 & 8.67 \\
\hline $\mathrm{CD}(\mathrm{P}=0.05)$ & 20.04 & 2.45 & 0.25 & 1.09 & 0.42 & 0.68 & 0.84 \\
\hline
\end{tabular}

Table.4 Effect of different sources of organic manures and inorganic fertilizers on growth and yield of rice [Source: Baishya et al., (2015]

\begin{tabular}{|c|c|c|c|c|c|}
\hline Treatments & $\begin{array}{c}\text { Plant } \\
\text { height }(\mathrm{cm})\end{array}$ & $\begin{array}{l}\text { Tillers } \\
\text { No }\end{array}$ & $\begin{array}{l}\text { Panicle } \\
\text { length }(\mathrm{cm})\end{array}$ & $\begin{array}{c}\text { Grain } \\
\text { yield } \\
\left(\mathbf{t} \mathbf{h a}^{-1}\right)\end{array}$ & $\begin{array}{c}\text { Straw } \\
\text { yield } \\
\left(\mathrm{t} \mathrm{ha}^{-1}\right)\end{array}$ \\
\hline Sesbania green manure (5t/ha) & 93.03 & 13.0 & 17.03 & 2.23 & 4.02 \\
\hline Sesbania green manure (5t/ha) $75 \% \mathrm{CDF}$ & 107.40 & 13.6 & 22.00 & 4.07 & 7.12 \\
\hline Sesbania green manure $(5 \mathrm{t} / \mathrm{ha})+100 \% \mathrm{CDF}$ & 110.33 & 13.9 & 23.20 & 4.43 & 7.45 \\
\hline Sesbania green manure $(5 \mathrm{t} / \mathrm{ha})+125 \% \mathrm{CDF}$ & 114.50 & 14.1 & 23.73 & 4.93 & 7.89 \\
\hline 5 t FYM ha $^{-1}$ & 93.30 & 12.4 & 16.20 & 3.07 & 5.52 \\
\hline 5 t FYM ha ${ }^{-1}+75 \%$ CDF & 103.50 & 13.5 & 17.37 & 4.63 & 7.88 \\
\hline 5 t FYM ha ${ }^{-1}+100 \%$ CDF & 106.27 & 14.0 & 22.07 & 4.90 & 8.18 \\
\hline 5 t FYM ha ${ }^{-1}+125 \%$ CDF & 110.37 & 14.3 & 23.23 & 5.37 & 8.59 \\
\hline $1 \mathrm{t}$ Vermicompost ha- ${ }^{-1}$ & 93.70 & 13.3 & 17.37 & 4.33 & $\mathbf{7 . 3 7}$ \\
\hline $1 \mathrm{t}$ Vermicompost ha ${ }^{-1}+75 \%$ CDF & 104.63 & 14.0 & 22.93 & 4.83 & 7.73 \\
\hline $1 \mathrm{t}$ Vermicompost $\mathrm{ha}^{-1}+100 \%$ CDF & 105.03 & 14.3 & 23.97 & 5.17 & 8.11 \\
\hline $1 \mathrm{t}$ Vermicompost $\mathrm{ha}^{-1}+125 \%$ CDF & 110.30 & 14.5 & 24.75 & 5.53 & 8.69 \\
\hline 2.5t Poultry manure ha $^{-1}$ & 92.47 & 12.7 & 17.27 & 3.87 & 6.57 \\
\hline 2.5t Poultry manure ha ${ }^{-1}+75 \%$ CDF & 107.47 & 13.7 & 23.67 & 5.33 & 8.53 \\
\hline 2.5t Poultry manure ha ${ }^{-1}+100 \%$ CDF & 110.40 & 14.5 & 24.63 & 5.60 & 8.85 \\
\hline 2.5t Poultry manure ha ${ }^{-1}+125 \%$ CDF & 112.27 & 14.6 & 24.93 & 6.03 & 9.41 \\
\hline $\mathrm{CD}(\mathbf{P}=\mathbf{0 . 0 5})$ & 6.24 & 1.3 & 1.40 & 0.25 & 0.43 \\
\hline
\end{tabular}


Table.5 Effect of fertility levels and bio-organics on yield and yield attributes of rice [Source: Kumar et al., 2017]

\begin{tabular}{|c|c|c|c|c|c|c|c|}
\hline Treatments & $\begin{array}{c}\text { Panicles } \\
\mathrm{m}^{-2}\end{array}$ & $\begin{array}{c}\text { illed grains } \\
\text { panicle }^{-1}\end{array}$ & $\begin{array}{l}\text { Unfilled } \\
\text { grains } \\
\text { panicle-1 }^{-1}\end{array}$ & $\begin{array}{l}\text { 1000- } \\
\text { grain } \\
\text { weight } \\
\text { (g) }\end{array}$ & $\begin{array}{l}\text { irain yield } \\
(\mathbf{q ~ h a - 1})\end{array}$ & $\begin{array}{l}\text { traw yield } \\
\qquad\left(\mathbf{q} \mathbf{h a}^{-1}\right)\end{array}$ & $\begin{array}{r}\text { Harvest } \\
\text { index } \\
(\%)\end{array}$ \\
\hline \multicolumn{8}{|c|}{ Fertility levels (\% RDF) } \\
\hline $\mathbf{0}$ & 181.31 & 166.66 & 26.66 & 12.92 & 31.27 & 57.15 & 35.33 \\
\hline 50 & 206.91 & 183.88 & 22.33 & 13.70 & 36.34 & 63.49 & 36.39 \\
\hline 75 & 214.28 & 193.33 & 18.55 & 13.82 & 40.28 & 68.65 & 36.96 \\
\hline 100 & 225.07 & 200.00 & 15.44 & 14.28 & 42.45 & 71.24 & 37.33 \\
\hline $\mathrm{CD}(P=0.05)$ & 6.39 & 6.61 & 2.39 & 0.36 & 0.92 & 1.96 & 0.31 \\
\hline \multicolumn{8}{|l|}{ Bio-organics } \\
\hline Control & 197.78 & 178.00 & 23.08 & 13.24 & 33.06 & 58.02 & 36.19 \\
\hline FYM & 205.93 & 188.08 & 21.00 & 13.74 & 38.93 & 67.49 & 36.53 \\
\hline FYM + BGA & 216.98 & 191.83 & 18.16 & 14.06 & 40.76 & 69.89 & 36.79 \\
\hline $\mathrm{CD}(P=0.05)$ & 5.53 & 5.05 & 2.07 & 0.31 & 0.80 & 1.70 & 0.27 \\
\hline
\end{tabular}

Table.6 Effect of INM on yield attributes, grain, straw yield and harvest index of rice [Source: Tiwari et al., 2017]

\begin{tabular}{|c|c|c|c|c|c|c|c|}
\hline Treatments & $\begin{array}{c}\text { Panicles } \\
\left(\mathbf{m}^{2}\right)\end{array}$ & $\begin{array}{l}\text { Panicle } \\
\text { length } \\
(\mathrm{cm})\end{array}$ & $\begin{array}{l}\text { Grains/ } \\
\text { panicle }\end{array}$ & $\begin{array}{l}\text { Test } \\
\text { wt. } \\
(\mathrm{g})\end{array}$ & $\begin{array}{c}\text { Grain } \\
\text { yield } \\
\left(\mathrm{kg} \mathrm{ha}^{-1}\right)\end{array}$ & $\begin{array}{c}\text { Straw } \\
\text { yield } \\
\left(\mathrm{kg} \mathrm{ha}^{-1}\right)\end{array}$ & $\begin{array}{c}\text { Harvest } \\
\text { Index } \\
(\%)\end{array}$ \\
\hline $\mathrm{T}_{1}$ :Control & 225.9 & 18.4 & 98.6 & 22.80 & 1440.0 & 2217.2 & 39.37 \\
\hline $\mathrm{T}_{2}: \mathbf{R} 25 \%$ & 276.9 & 22.6 & 120.8 & 22.95 & 3344.2 & 4448.0 & 42.92 \\
\hline $\mathrm{T}_{\mathbf{3}}: \mathbf{R 5 0 \%}$ & 280.0 & 22.9 & 120.9 & 23.20 & 3475.0 & 4586.7 & 43.10 \\
\hline $\mathbf{T}_{\mathbf{4}}: \mathbf{R 7 5 \%}$ & 292.7 & 23.9 & 127.7 & 23.35 & 4138.0 & 5212.2 & 43.48 \\
\hline $\mathrm{T}_{5}: \mathrm{R} 100 \%$ & 324.6 & 26.5 & 141.6 & 23.85 & 5113.0 & 6647.2 & 44.26 \\
\hline $\mathrm{T}_{6}: \mathrm{R50} \%+50 \% \mathrm{FYM}$ & 345.2 & 28.9 & 156.1 & 24.20 & 5459.0 & 7042.0 & 43.67 \\
\hline $\mathrm{T}_{7}: \mathrm{R75} \%+25 \% \mathrm{FYM}$ & 329.3 & 27.6 & 148.9 & 23.30 & 5208.0 & 6770.0 & 43.48 \\
\hline $\mathrm{T}_{8}: \mathrm{R50} \%+50 \% \mathrm{WCS}$ & 304.7 & 24.5 & 136.5 & 23.10 & 4249.0 & 5449.7 & 43.82 \\
\hline T9:R75\%+25\%WCS & 310.8 & 24.9 & 138.2 & 23.20 & 4519.0 & 5919.2 & 43.29 \\
\hline $\mathrm{T}_{10}: \mathbf{R 5 0 \% + 5 0 \% G M}$ & 332.8 & 27.9 & 150.5 & 24.10 & 5263.0 & 6736.7 & 43.86 \\
\hline $\mathrm{T}_{11}: \mathrm{R} 75 \%+25 \% \mathrm{GM}$ & 321.7 & 27.0 & 145.5 & 23.40 & 5087.0 & 6561.7 & 43.67 \\
\hline $\mathbf{T}_{12}$ :Farmers practice & 290.0 & 23.7 & 126.1 & 23.00 & 3850.0 & 5158.5 & 42.74 \\
\hline $\mathrm{CD}$ at $5 \%$ & 30.308 & 2.085 & 12.112 & NS & 271.209 & 353.778 & 0.977 \\
\hline
\end{tabular}


Table.7 Effect of INM on Grain yield, Straw yield and Harvest index [Source: Singh et al., 2018]

\begin{tabular}{|c|c|c|c|}
\hline Treatments & $\begin{array}{l}\text { Grain yield } \\
\qquad\left(\mathbf{q} \mathbf{h a}^{-1}\right)\end{array}$ & $\begin{array}{c}\text { Straw } \\
\text { yield } \\
\left(\mathbf{q} \mathbf{h a}^{-1}\right)\end{array}$ & $\begin{array}{c}\text { Harvest } \\
\text { index }(\%)\end{array}$ \\
\hline $\mathrm{T}_{1}$ : Control & 9.35 & 12.63 & 42.53 \\
\hline $\mathrm{T}_{2}: \mathbf{5 0 \%} \mathrm{RDF}$ & 27.59 & 35.31 & 43.87 \\
\hline $\mathrm{T}_{3}: 75 \% \mathrm{RDF}$ & 36.01 & 45.02 & 44.44 \\
\hline $\mathrm{T}_{4}: 100 \% \mathrm{RDF}$ & 49.12 & 60.41 & 44.85 \\
\hline $\mathrm{T}_{5}: \mathbf{5 0 \%} \mathrm{RDF}+\mathbf{5 0 \%} \mathrm{FYM}$ & 55.10 & 66.94 & 45.26 \\
\hline $\mathrm{T}_{6}: 75 \% \mathrm{RDF}+25 \% \mathrm{FYM}$ & 50.46 & 61.05 & 45.18 \\
\hline $\mathrm{T}_{7}: \mathbf{5 0 \%} \mathrm{RDF}+\mathbf{5 0} \% \mathrm{WS}$ & 52.80 & 64.39 & 45.06 \\
\hline $\mathrm{T}_{8}: 75 \% \mathrm{RDF}+25 \% \mathrm{WS}$ & 49.65 & 60.57 & 45.04 \\
\hline $\mathrm{T}_{9}: 50 \% \mathrm{RDF}+50 \% \mathrm{GM}$ & 54.79 & 66.29 & 45.25 \\
\hline $\mathrm{T}_{10}: 75 \% \mathrm{RDF}+25 \% \mathrm{GM}$ & 50.27 & 60.82 & 45.25 \\
\hline $\mathrm{CD}(\mathrm{P}=0.05)$ & 4.28 & 4.98 & 1.54 \\
\hline
\end{tabular}

Table.8 Effect of Organic and Inorganic Sources of Nutrients on No. of Effective tillers hill ${ }^{-1}$, Number of spikelets panicle ${ }^{-1}$, Number of filled spikelets panicle ${ }^{-1}(\%)$, Test weight (g), Grain Yield $\left(\mathrm{kg} \mathrm{ha}^{-1}\right)$, and Straw Yield $\left(\mathrm{kg} \mathrm{ha}^{-1}\right)$

\begin{tabular}{|c|c|c|c|c|c|c|c|c|}
\hline & Treatment & $\begin{array}{c}\text { No. of effective } \\
\text { tillers/hill }\end{array}$ & $\begin{array}{c}\text { Number of } \\
\text { spikelets/panicle }\end{array}$ & $\begin{array}{c}\text { Number of filled } \\
\text { spikelets/panicle (\%) }\end{array}$ & $\begin{array}{c}\text { Test } \\
\text { weight } \\
(\mathrm{g})\end{array}$ & $\begin{array}{c}\text { Grain } \\
\text { Yield } \\
(\mathrm{kg} / \mathrm{ha})\end{array}$ & $\begin{array}{c}\text { Straw } \\
\text { Yield } \\
(\mathrm{kg} / \mathrm{ha})\end{array}$ & $\begin{array}{c}\text { Grain } \\
\text { Protein } \\
(\%)\end{array}$ \\
\hline $\mathrm{T}_{1}$ & FYM @ 5 tonnes ha ${ }^{-1}$ & 5.73 & 123.07 & 79.54 & 22.17 & 2466.67 & 7466.67 & 11.067 \\
\hline $\mathrm{T}_{2}$ & FYM @ 10 tonnes ha ${ }^{-1}$ & 6.30 & 135.47 & 80.48 & 22.45 & 2700.00 & 8066.67 & 11.230 \\
\hline $\mathrm{T}_{3}$ & $50 \% \mathrm{RDF}$ & 6.90 & 143.47 & 80.39 & 23.56 & 2778.33 & 8200.00 & 12.143 \\
\hline $\mathrm{T}_{4}$ & $75 \% \mathrm{RDF}$ & 7.40 & 158.07 & 82.43 & 23.74 & 3300.00 & 9583.33 & 12.213 \\
\hline $\mathrm{T}_{5}$ & $100 \% \mathrm{RDF}$ & 8.23 & 172.93 & 83.43 & 23.76 & 3533.33 & 10383.33 & 12.407 \\
\hline $\mathrm{T}_{6}$ & FYM $@ 5$ tonnes ha ${ }^{-1}+50 \%$ RDF & 8.27 & 164.47 & 85.50 & 23.35 & 3500.00 & 10333.33 & 12.617 \\
\hline $\mathrm{T}_{7}$ & FYM @ 5 tonnes ha- ${ }^{-1}+75 \%$ RDF & 9.17 & 186.40 & 85.41 & 23.56 & 4133.33 & 12300.00 & 12.693 \\
\hline $\mathrm{T}_{8}$ & FYM @ 0 tonnes ha ${ }^{-1}+100 \%$ RDF & 9.77 & 202.13 & 86.57 & 23.96 & 4500.00 & 12666.67 & 13.063 \\
\hline $\mathrm{T}_{9}$ & FYM @ 10 tonnes ha ${ }^{-1}+50 \%$ RDF & 9.70 & 198.00 & 84.36 & 24.00 & 4400.00 & 12583.33 & 12.993 \\
\hline T10 & FYM @ 10 tonnes ha ${ }^{-1}+75 \%$ RDF & 11.03 & 212.47 & 86.98 & 24.26 & 4623.33 & 13033.33 & 13.143 \\
\hline$T_{11}$ & FYM @ 10 tonnes ha ${ }^{-1}+100 \%$ RDF & 11.70 & 230.40 & 87.67 & 24.66 & 5016.67 & 13550.00 & 13.203 \\
\hline $\mathrm{T}_{12}$ & No manure and fertilizer & 5.10 & 114.40 & 77.49 & 22.00 & 2033.33 & 7016.67 & 10.000 \\
\hline & F test & $\mathrm{S}$ & S & S & $\mathrm{S}$ & S & $S$ & $\mathrm{~S}$ \\
\hline & $\operatorname{SEd}( \pm)$ & 0.28 & 10.95 & 1.68 & 0.73 & 297.61 & 691.72 & 0.93 \\
\hline & $\mathrm{CD}(\mathrm{P}=0.05)$ & 0.59 & 22.71 & 3.48 & 1.52 & 617.21 & 1434.55 & 1.93 \\
\hline & $\mathrm{CV}(\%)$ & 4.18 & 7.88 & 2.47 & 3.83 & 10.18 & 8.12 & 9.31 \\
\hline
\end{tabular}

*RDF- Recommended Dose of Fertilizer through inorganic fertilizers i.e., $70-40-40 \mathrm{~kg} \mathrm{ha}^{-1}$ (N-P-K) FYM: Farmyard Manure 
Table.9 Status of organic carbon, available $\mathrm{N}, \mathrm{P}_{2} \mathrm{O}_{5}$ and $\mathrm{K}_{2} \mathrm{O}$ in post-harvest soil [Source: Baishya et al., 2015]

\begin{tabular}{|c|c|c|c|c|}
\hline Treatments & $\begin{array}{c}\text { Organic } \\
\text { carbon } \\
\left(\mathrm{g} \mathrm{kg}^{-1}\right)\end{array}$ & $\begin{array}{c}\text { Availa } \\
\text { ble N } \\
\left(\begin{array}{c}\text { kg ha- } \\
1\end{array}\right)\end{array}$ & $\begin{array}{c}\text { Available } \\
\mathrm{P}_{2} \mathrm{O}_{5} \\
\left(\mathrm{~kg} \mathrm{ha}^{-1}\right)\end{array}$ & $\begin{array}{c}\text { Availabl } \\
\text { e } \mathrm{K}_{2} \mathrm{O} \\
\left(\mathrm{kg} \mathrm{ha}^{-1}\right)\end{array}$ \\
\hline Sesbania green manure (5t/ha) & 7.8 & 166.6 & 23.3 & 61.0 \\
\hline $\begin{array}{l}\text { Sesbania green manure (5t/ha) + } 75 \% \\
\text { CDF }\end{array}$ & 7.9 & 181.6 & 28.1 & 74.0 \\
\hline $\begin{array}{l}\text { Sesbania green manure }(5 \mathrm{t} / \mathrm{ha})+ \\
100 \% \mathrm{CDF}\end{array}$ & 8.1 & 193.3 & 28.4 & 78.6 \\
\hline $\begin{array}{l}\text { Sesbania green manure }(5 \mathrm{t} / \mathrm{ha})+ \\
125 \% \mathrm{CDF}\end{array}$ & 8.8 & 198.7 & 29.0 & 80.0 \\
\hline 5 t FYM ha ${ }^{-1}$ & 8.1 & 182.0 & 25.7 & 81.6 \\
\hline 5 t FYM ha ${ }^{-1}+75 \%$ CDF & 8.6 & 188.6 & 26.8 & 73.8 \\
\hline 5 t FYM ha ${ }^{-1}+100 \%$ CDF & 8.9 & 198.1 & 27.7 & 78.5 \\
\hline 5 t FYM ha ${ }^{-1}+125 \%$ CDF & 9.0 & 202.3 & 28.1 & 80.5 \\
\hline $1 \mathrm{t}$ Vermicompost $\mathrm{ha}^{-1}$ & 7.9 & 185.0 & 23.5 & 80.6 \\
\hline 1 t Vermicompost ha $^{-1}+75 \%$ CDF & 8.2 & 192.3 & 24.7 & 82.6 \\
\hline 1 t Vermicompost $\mathrm{ha}^{-1}+100 \% \mathrm{CDF}$ & 8.5 & 198.0 & 25.3 & 86.5 \\
\hline $1 \mathrm{t}$ Vermicompost $\mathrm{ha}^{-1}+125 \%$ CDF & 8.2 & 202.5 & 26.6 & 90.0 \\
\hline 2.5t Poultry manure ha ${ }^{-1}$ & 7.7 & 183.5 & 25.6 & 79.6 \\
\hline 2.5t Poultry manure ha ${ }^{-1}+75 \%$ CDF & 8.9 & 192.6 & 28.8 & 88.3 \\
\hline 2.5t Poultry manure $\mathrm{ha}^{-1}+100 \% \mathrm{CDF}$ & 9.2 & 197.3 & 31.0 & 90.3 \\
\hline 2.5t Poultry manure $\mathrm{ha}^{-1}+125 \% \mathrm{CDF}$ & 9.4 & 203.0 & 32.0 & 92.3 \\
\hline CD at $5 \%$ & 0.6 & 6.82 & 1.71 & 2.7 \\
\hline
\end{tabular}

Table.10 Hulling, milling and broken rice percentages of rice cv. Sakha 106 as influenced by the interaction between nitrogen rate and compost rate in 2012 and 2013 seasons

\begin{tabular}{|c|c|c|c|c|c|}
\hline \multirow{2}{*}{$\mathrm{KgN} \mathrm{ha}^{-1}$} & \multirow{2}{*}{ Compost / $\mathrm{t} \mathrm{ha}^{-1}$} & \multirow{2}{*}{$\begin{array}{l}\text { Hulling (\%) } \\
2013\end{array}$} & \multirow{2}{*}{$\begin{array}{c}\text { Milling (\%) } \\
2012\end{array}$} & \multicolumn{2}{|c|}{ Broken rice (\%) } \\
\hline & & & & 2012 & 2013 \\
\hline \multirow{3}{*}{0} & 0 & $81.79 \mathrm{f}$ & $70.25 \mathrm{~g}$ & $12.53 \mathrm{a}$ & $11.95 \mathrm{a}$ \\
\hline & 3.5 & $82.17 \mathrm{e}$ & $71.86 \mathrm{f}$ & $11.18 \mathrm{~b}$ & $10.85 \mathrm{~b}$ \\
\hline & 7 & $82.37 \mathrm{de}$ & 72.66 ef & $10.57 \mathrm{bc}$ & $10.50 \mathrm{bc}$ \\
\hline \multirow{3}{*}{55} & 0 & $82.22 \mathrm{e}$ & 73.00 ef & $9.780 \mathrm{~cd}$ & $10.30 \mathrm{bcd}$ \\
\hline & 3.5 & 82.44 cde & 73.22 def & $8.990 \mathrm{de}$ & $9.980 \mathrm{cde}$ \\
\hline & 7 & $82.62 \mathrm{bcd}$ & 74.12 cde & $8.780 \mathrm{de}$ & 9.600 ef \\
\hline \multirow{3}{*}{110} & 0 & $82.49 \mathrm{cde}$ & $74.16 \mathrm{cde}$ & $8.960 \mathrm{de}$ & $10.43 \mathrm{bc}$ \\
\hline & 3.5 & $82.67 \mathrm{bcd}$ & $74.81 \mathrm{bcd}$ & $8.500 \mathrm{e}$ & $9.480 \mathrm{ef}$ \\
\hline & 7 & $82.83 \mathrm{ab}$ & $75.46 a b c$ & $8.280 \mathrm{e}$ & $9.240 \mathrm{fg}$ \\
\hline \multirow{3}{*}{165} & 0 & $82.71 \mathrm{bc}$ & $76.00 \mathrm{ab}$ & $8.790 \mathrm{de}$ & $9.830 \mathrm{def}$ \\
\hline & 3.5 & $82.86 \mathrm{ab}$ & $77.05 \mathrm{a}$ & $8.640 \mathrm{de}$ & $8.790 \mathrm{~g}$ \\
\hline & 7 & $83.05 \mathrm{a}$ & $77.08 \mathrm{a}$ & $8.300 \mathrm{e}$ & $8.010 \mathrm{~h}$ \\
\hline
\end{tabular}

Means of each column designated by the same letter are not significantly different at $5 \%$ level usina Duncan's multiple ranae test. 
Table.11 Hulling, milling, broken rice and amylose percentages of rice cv. Sakha 106 as affected by the interaction between nitrogen rate and foliar application of ascobien in 2012 and 2013

seasons

\begin{tabular}{|c|c|c|c|c|c|c|c|}
\hline \multirow{2}{*}{$\begin{array}{l}\mathrm{Kg} \mathrm{N} \\
\mathrm{ha}^{-1}\end{array}$} & \multirow{2}{*}{$\begin{array}{c}\text { Ascobien } \\
\text { spray }\end{array}$} & \multicolumn{2}{|c|}{ Hulling (\%) } & \multicolumn{2}{|c|}{ Milling (\%) } & \multicolumn{2}{|c|}{ Broken rice (\%) } \\
\hline & & 2012 & 2013 & 2012 & 2013 & 2012 & 2013 \\
\hline \multirow{3}{*}{0} & 0 & $83.46 \mathrm{~g}$ & $81.90 \mathrm{f}$ & $70.61 \mathrm{~h}$ & $71.27 \mathrm{i}$ & $12.87 \mathrm{a}$ & $11.88 \mathrm{a}$ \\
\hline & 2 times & $84.51 \mathrm{ef}$ & 82.16 ef & $71.78 \mathrm{~g}$ & $71.49 \mathrm{~h}$ & $11.63 b$ & $11.46 \mathrm{a}$ \\
\hline & 3 times & $85.46 \mathrm{~cd}$ & $82.28 \mathrm{de}$ & $72.38 \mathrm{fg}$ & $71.58 \mathrm{gh}$ & $9.770 \mathrm{~d}$ & $9.96 \mathrm{bcd}$ \\
\hline \multirow{3}{*}{55} & 0 & $84.06 \mathrm{f}$ & $82.31 \mathrm{de}$ & $72.66 \mathrm{fg}$ & $71.65 \mathrm{gh}$ & $10.50 \mathrm{c}$ & $11.53 \mathrm{a}$ \\
\hline & 2 times & $85.11 \mathrm{de}$ & $82.44 \mathrm{cde}$ & $72.94 \mathrm{f}$ & $71.78 \mathrm{fg}$ & 8.750 ef & $10.33 b c$ \\
\hline & 3 times & $86.02 b c$ & $82.53 \mathrm{bcd}$ & $74.74 \mathrm{de}$ & 71.96 ef & 8.480 ef & $9.500 \mathrm{de}$ \\
\hline \multirow{3}{*}{110} & 0 & $85.02 \mathrm{de}$ & $82.57 \mathrm{bcd}$ & $74.27 \mathrm{e}$ & $71.99 \mathrm{e}$ & 8.980 ef & $10.37 \mathrm{~b}$ \\
\hline & 2 times & $85.52 \mathrm{~cd}$ & $82.66 \mathrm{bc}$ & $74.34 \mathrm{e}$ & $72.12 \mathrm{de}$ & 8.490 ef & $9.770 \mathrm{~cd}$ \\
\hline & 3 times & $86.35 \mathrm{~b}$ & $82.76 \mathrm{abc}$ & $75.81 \mathrm{bc}$ & $72.30 \mathrm{~cd}$ & 8.280 ef & $9.030 \mathrm{ef}$ \\
\hline \multirow{3}{*}{165} & 0 & $85.66 \mathrm{~cd}$ & $82.78 \mathrm{ab}$ & $75.49 \mathrm{~cd}$ & $72.38 \mathrm{bc}$ & $9.010 \mathrm{e}$ & $9.520 \mathrm{de}$ \\
\hline & 2 times & $86.34 \mathrm{~b}$ & $82.84 \mathrm{ab}$ & $76.64 \mathrm{~b}$ & $72.52 \mathrm{ab}$ & 8.500 ef & $8.810 \mathrm{fg}$ \\
\hline & 3 times & $87.03 \mathrm{a}$ & $83.00 \mathrm{a}$ & $78.00 \mathrm{a}$ & $72.65 \mathrm{a}$ & $8.220 \mathrm{f}$ & $8.310 \mathrm{~g}$ \\
\hline
\end{tabular}

Table.12 Effect of INM treatments on grain and cooking quality of basmati rice

\begin{tabular}{|c|c|c|c|c|c|c|c|c|}
\hline \multirow[t]{2}{*}{ Treatment } & \multicolumn{3}{|c|}{ Rice recovery (\%) } & \multirow{2}{*}{$\begin{array}{l}\text { Minimum } \\
\text { cooking } \\
\text { time (min) }\end{array}$} & \multirow{2}{*}{$\begin{array}{l}\text { Water } \\
\text { absorption } \\
\text { ratio }\end{array}$} & \multirow{2}{*}{$\begin{array}{l}\text { Elongation } \\
\text { ratio }\end{array}$} & \multirow{2}{*}{$\begin{array}{l}\text { Cooking } \\
\text { coefficient }\end{array}$} & \multirow{2}{*}{$\begin{array}{c}\text { Protein } \\
\text { content } \\
(\%)\end{array}$} \\
\hline & Brown & Milled & Head & & & & & \\
\hline $\mathrm{T}_{1}(\mathrm{RN})$ & 77.7 & 68.4 & 54.4 & 16.44 & 3.27 & 1.61 & 5.45 & 7.37 \\
\hline $\mathrm{T}_{2}(\mathrm{GM})$ & 77.6 & 68.9 & 55.5 & 16.46 & 3.22 & 1.62 & 5.71 & 7.36 \\
\hline $\mathrm{T}_{3}(\mathrm{GM}+25 \% \mathrm{RN})$ & 76.7 & 68.1 & 52.9 & 16.45 & 3.15 & 1.60 & 5.45 & 7.40 \\
\hline $\mathrm{T}_{4}^{3}(\mathrm{GM}+50 \% \mathrm{RN})$ & 76.2 & 67.2 & 52.4 & 16.35 & 3.16 & 1.56 & 5.68 & 7.48 \\
\hline $\mathrm{T}_{5}(\mathrm{FYM})$ & 74.8 & 65.9 & 51.1 & 16.30 & 3.13 & 1.58 & 5.48 & 7.18 \\
\hline $\mathrm{T}_{6}(\mathrm{FYM}+25 \% \mathrm{RN})$ & 77.3 & 69.6 & 54.2 & 16.42 & 3.21 & 1.57 & 5.56 & 7.18 \\
\hline $\mathrm{T}_{7}(\mathrm{FYM}+50 \% \mathrm{RN})$ & 78.7 & 70.3 & 57.3 & 16.48 & 3.26 & 1.63 & 5.58 & 7.66 \\
\hline $\mathrm{T}_{s}(\mathrm{FYM}+\mathrm{GM})$ & 78.1 & 69.6 & 56.7 & 16.48 & 3.17 & 1.62 & 5.56 & 7.54 \\
\hline $\mathrm{T}_{9}($ Control $)$ & 73.3 & 64.4 & 49.1 & 16.35 & 3.09 & 1.56 & 5.52 & 7.05 \\
\hline $\mathrm{SEm} \pm$ & 0.67 & 0.70 & 0.73 & 0.09 & 0.07 & 0.02 & 0.23 & 0.04 \\
\hline $\mathrm{CD}(\mathrm{P}=0.05)$ & 2.0 & 2.1 & 2.2 & NS & NS & 0.05 & NS & 0.12 \\
\hline
\end{tabular}

$\mathrm{T}_{1},(\mathrm{RN})$, Recommended nitrogen $40 \mathrm{~kg} \mathrm{~N} / \mathrm{ha} ; \mathrm{T}_{2},(\mathrm{GM})$, green manure; $\mathrm{T}_{3}, \mathrm{GM}+25 \% \mathrm{RN} ; \mathrm{T}_{4}, \mathrm{GM}+50 \% \mathrm{RN} ; \mathrm{T}_{5},(\mathrm{FYM})$ farmyard manure to supply $40 \mathrm{~kg} \mathrm{~N} / \mathrm{ha} ; \mathrm{T}_{6}, \mathrm{FYM}+25 \% \mathrm{RN} ; \mathrm{T}_{7}, \mathrm{FYM}+50 \% \mathrm{RN} ; \mathrm{T}_{8}, \mathrm{FYM}+\mathrm{GM} ; \mathrm{T}_{9}$, unfertilized control

Fig.1 Tiller number (a) and Dry matter $\left(\mathrm{t} \mathrm{ha}^{-1}\right)[\mathrm{b}]$ of rice as affected by organic fertilizers at the critical growth stages [Source: Moe et al., 2019]
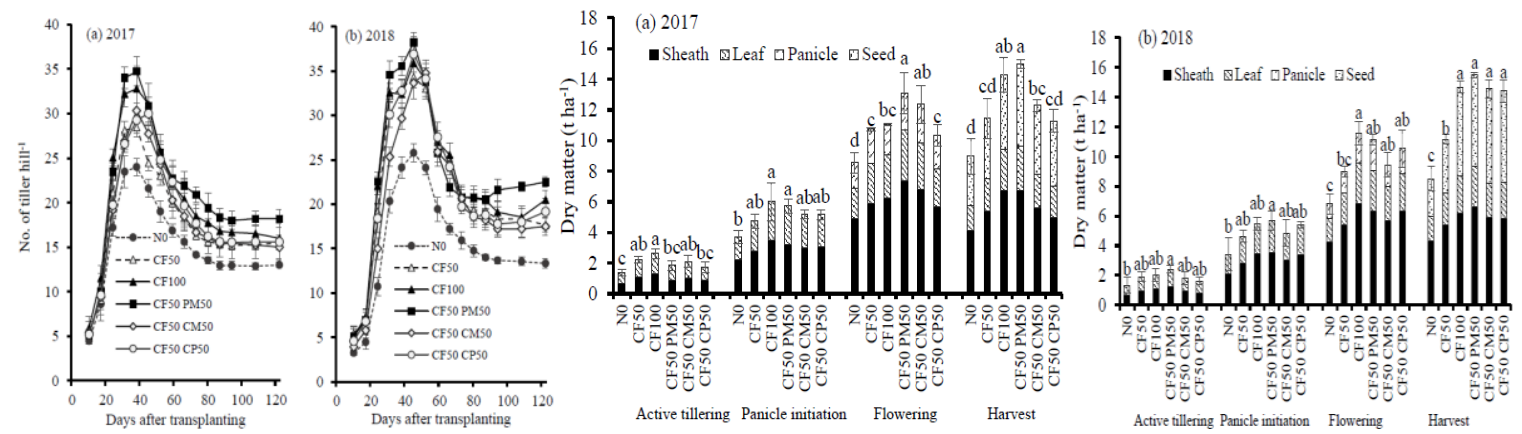
Fig.2(a): Changes in biomass accumulation during at early (A) and late season (B), $\mathrm{N}$ accumulation during early $(\mathbf{C})$ and late season $(\mathbf{D})$, nitrogen use efficiency during early $(\mathbf{E})$ and

late season $(\mathbf{F})$, and root-to-shoot ratio during early $(\mathbf{G})$ and late season $(\mathbf{H})$ of rice at the tillering, heading, and maturity stages under organic manure and inorganic fertilizer application [Source: Iqbal et al., 2019].

Note- $\mathrm{T}_{1}:$ no $\mathrm{N}$ fertilizer, $\mathrm{T}_{2}: 100 \% \mathrm{CF}, \mathrm{T}_{3}: 60 \% \mathrm{CM}+40 \% \mathrm{CF}, \mathrm{T}_{4}: 30 \% \mathrm{CM}+70 \% \mathrm{CF}, \mathrm{T}_{5}$ : $60 \% \mathrm{PM}+40 \% \mathrm{CF}, \mathrm{T}_{6}: 30 \% \mathrm{PM}+70 \% \mathrm{CF}$.

Fig. 2(b): Tillering pattern of hybrid rice as affected by combined application of organic manures and inorganic fertilizers in (a) dry season and (b) [Source Moe et al., 2017].

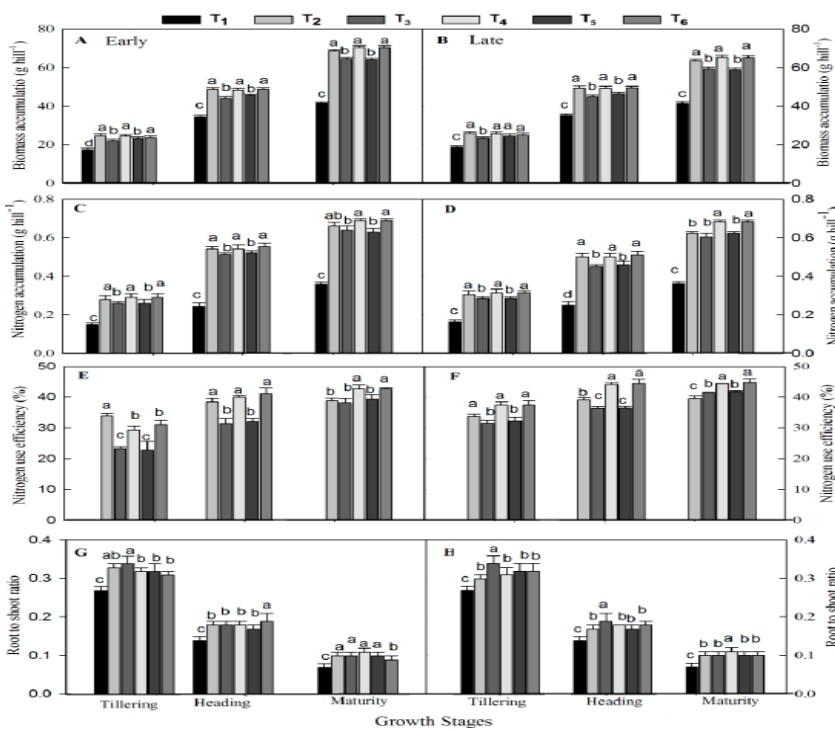

(a)

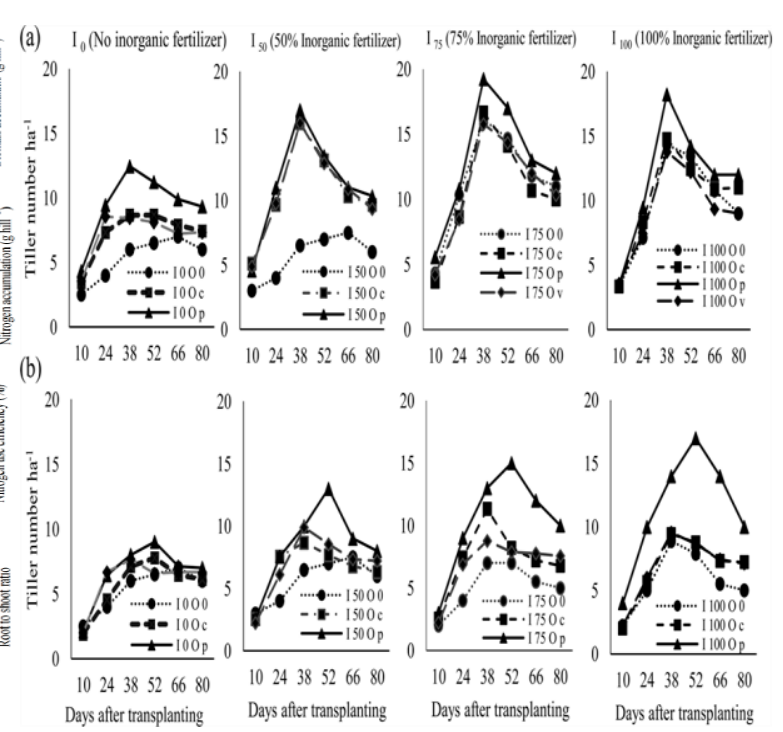

(b)

Fig.3 Effect of mixing organic and inorganic fertilizer on soil fertility and productivity

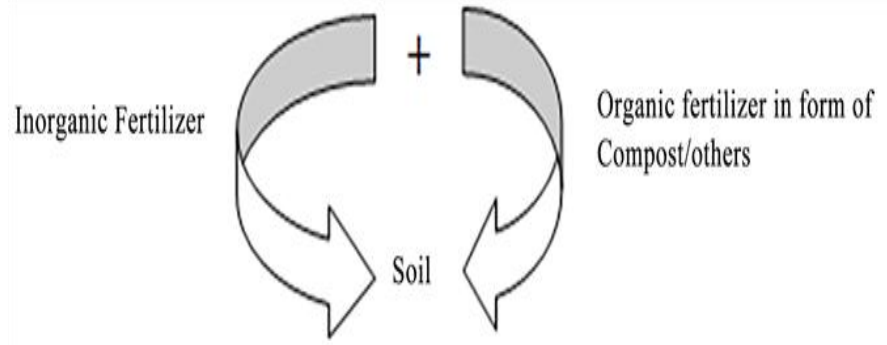

Best management system for increasing soil fertility

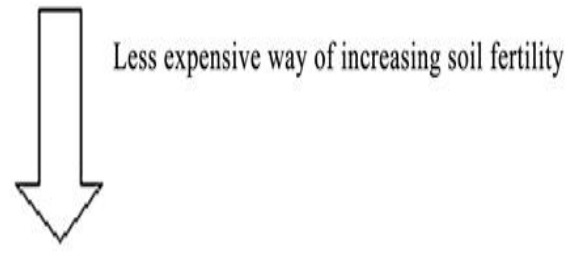

High Productivity 
Fig.4 Mean of nutrients for inputs and outputs, and the principles of integrated nutrient management systems [Source: Wu and Ma, 2015]

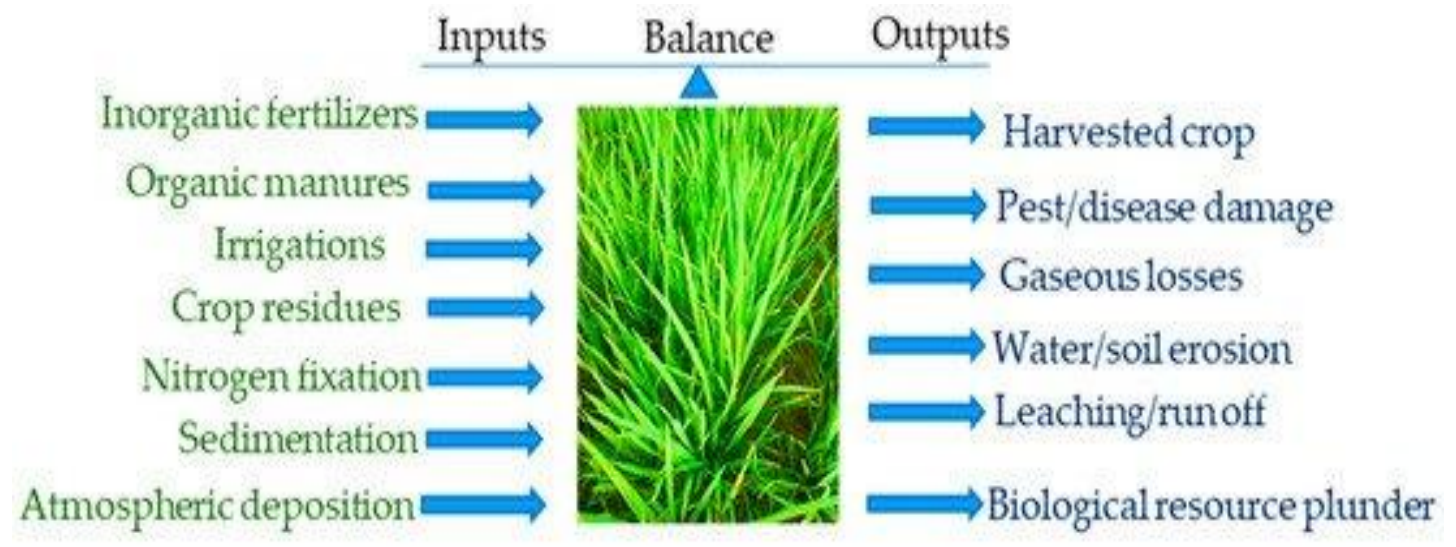

INM method based on inputs and outputs:

- Matching the quantity with demand of the crop

- Synchuronizing in terms of time with crop growth

Fig. 5 (a): Role of P solubilizing microorganisms (PSMs) in enhancing P mineral fertilizers ecoefficiency. PSM increase bioavailable P either directly by the production of low molecular weight organic acids, thus chelating through their carboxylic groups, cations attached to insoluble $\mathrm{P}$, or indirectly by synthetizing bioactive molecules (phytohormones, siderophore, antibiotics, etc.) which improve plant vitality and resilience to biotic and abiotic stress and ultimately leads to better nutrients uptake and agronomic yield.

Fig. 5(b): Schematic representation of the effect of organic amendments on soil properties by acting as a source of carbon and nitrogen

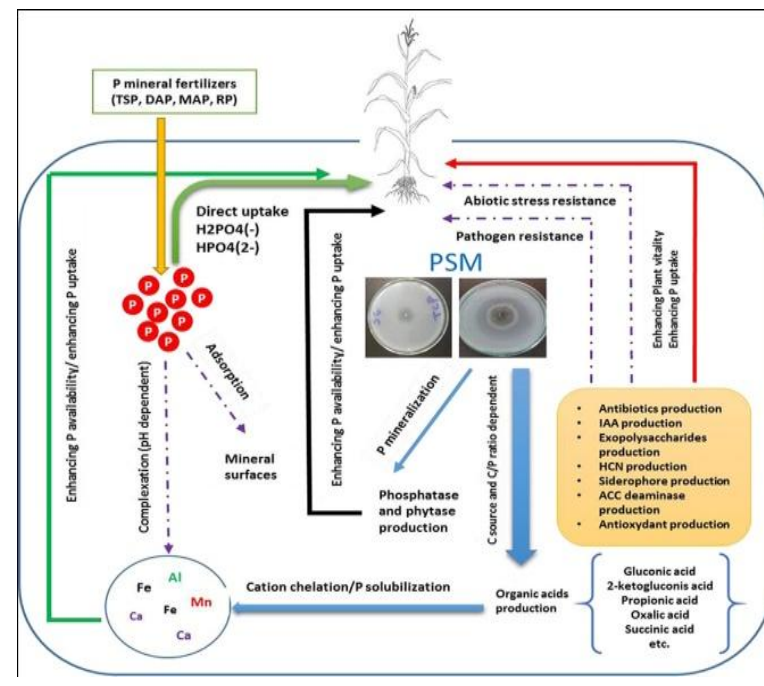

(a)

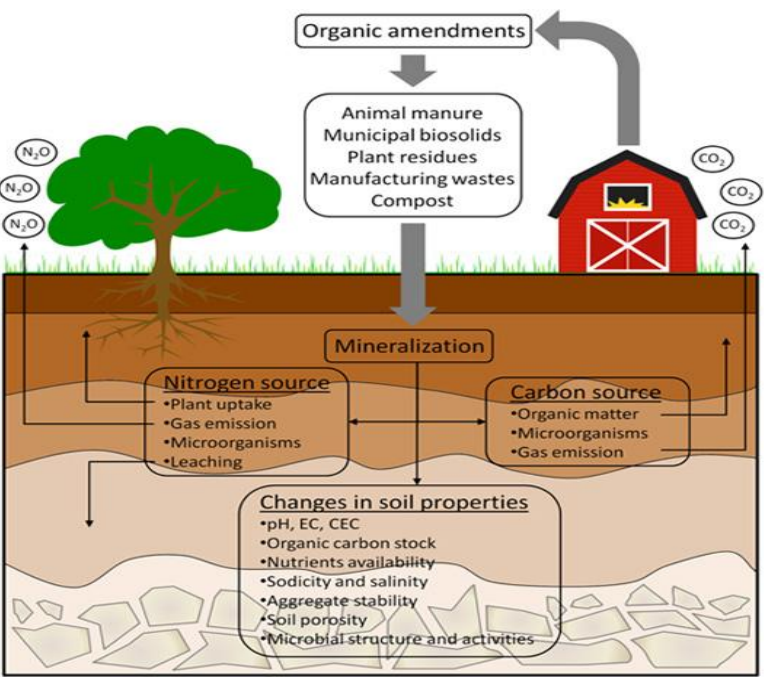

(b) 
Fig. 6(a): The benefits of biochar applied as a tool for soil fertility management

Fig. 6(b): The possible mechanisms for improving soil fertility

Fig. 6(c): The possible improvements of soil properties and fertility after biochar application

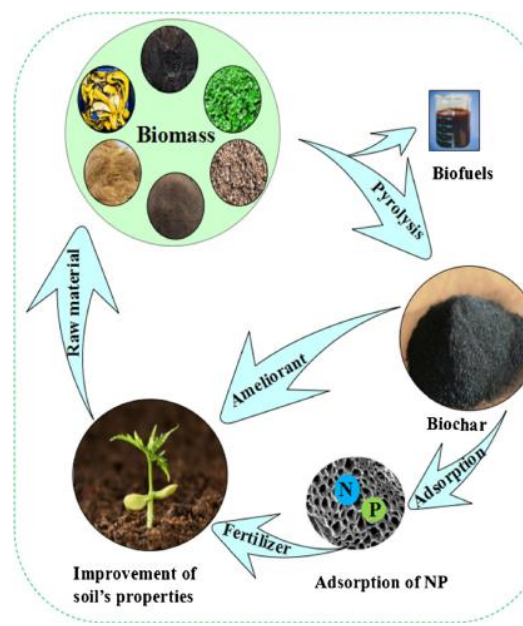

(a)

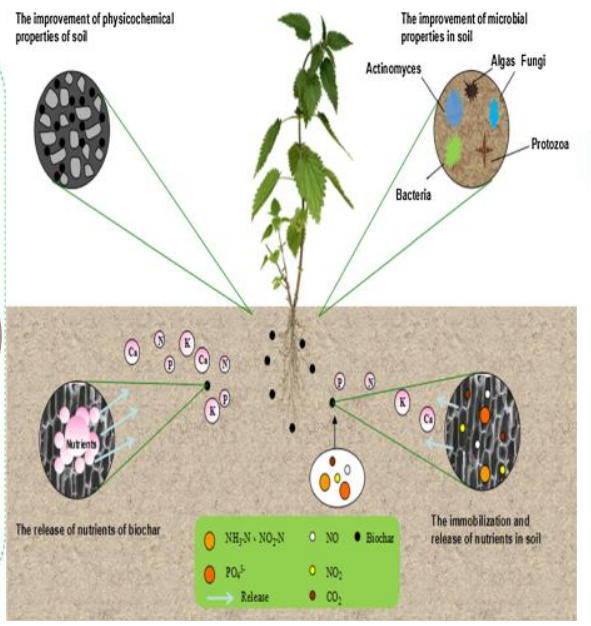

(b)

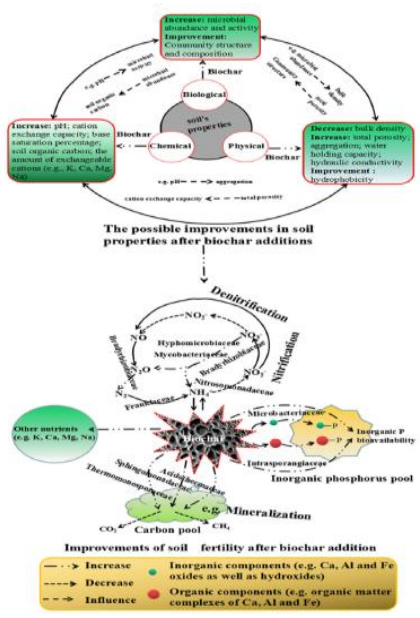

(c)
In conclusion, this review paper emphasized the role and importance of an integrated nutrient management system i.e. organic and inorganic nutrient sources as a management strategy that can bring sustainability to the rice crop of the Indian subcontinent. Organic fertilizers have more benefits in the long run compared to inorganic fertilizers. Organic fertilizer improves physical, biological, and chemical properties of a soil but the nutrients may not be as readily available to the plants. However, inorganic fertilizer is usually immediately and fast containing all necessary nutrients that are ready for plants. The excess use of inorganic fertilizers in agriculture can lead to soil deterioration, soil acidification and environment pollution. The integrated soil fertility management system is an alternative approach for the sustainable and cost-effective management of soil fertility and is characterized by reduced input of inorganic fertilizers and combined use of inorganic fertilizers with organic materials. Combined applications of organic and inorganic fertilizers improve soil fertility, productivity and reduce the impact of inorganic fertilizer on environment. So, it is an alternative way for sustainable soil fertility and productivity. On the basis of foregoing discussion it can be concluded that integrated use of fertilizers along with organics enhanced the productivity of rice. Combined application of farm yard manure, vermin-compost, bio-fertilizers, blue green algae and other organics with $100 \%$ RDF resulted in good growth parameters, yield attributes, significantly higher yield, grain quality of rice. Integrated nutrient management strategies provide the scientific basis for balanced fertilization not only between the fertilizer nutrients themselves but also that with the soil available nutrients. Integrated treatments involving inorganic and organic sources had pronounced influence in improving available nitrogen status as well as microbial activity compared to recommended dose of fertilizers. Moreover, the combined application of FYM + BGA with $100 \%$ RDF resulted in good growth parameters, yield attributes and significantly higher yield. Finally, the findings suggested that INM may be one of the viable nutrient management options in the Indian subcontinent, particularly for the rice crop. 


\section{References}

Ali, M.E., Islam, M.R. and Jahiruddin, M. 2009. Effect of Integrated Use of Organic Manures with Chemical Fertilizers in the Rice-Rice Cropping System and Its Impact on Soil Health. Bangladesh J Agri Sci. 34: 81-90.

Anonymous 2018. Agriculture statistics at a glance, Department of Agriculture and Co-operation, Ministry of Agriculture, Government of India, New Delhi.

Ansari, A. A. and Kumar, S. 2010. Effect of vermiwash and vermicompost on soil parameters and productivity of okra (Abelmoschus esculentus) in Guyana. Curr Adv Agri Sci, 2 (1): 1-4.

Asai H, Samson BK, Stephan HM, Songyikhangsuthor K, Homma K,Kiyono $\mathrm{Y}$, Inoue $\mathrm{Y}$, Shiraiwa $\mathrm{T}$, Horie $\mathrm{T}$. 2009.Biochar amendment techniques for upland rice production in Northern Laos, 1. Soilphysical properties, leaf SPAD and grain yield. Field Crop Res. 111:81-84.

Aulakh, C.S., P. Kaur, P., Walia, S.S., R.S. Gill, R.S., S. Sharma, S., and Buttar, G.S. 2016. Productivity and quality of basmati rice (Oryza sativa) in relation tonitrogen management. Indian J Agron 61 (4): 467473

Baghdadi, A.,Ridzwan A.,Halim, A. G., Mohd F. R., and Sakimin, S.Z. 2018.Impact of organic and inorganic fertilizers on the yield and quality of silage corn intercropped with soybean. Peer J. 6: e5280.

Baishya, L.K., Rathore, S.S., Singh, D., Sarkar, D. and Deka, B.C. 2015.Effect of integrated nutrient management on rice productivity, profitability and soil fertility. Ann Plant Soil Res. 17(1): 86-90.

Barik, A. K., Raj, A. and Saha, R. K. 2008. Yield performance, economics and soil fertility through organic sources (vermicompost) of nitrogen as substitute to chemical fertilizers in wet season rice. Crop Res. 36(1):4-7

Becker, M., Ladha, J. K. and Ottow, J. C. G. 1994. Nitrogen losses and lowland rice yield as affected by residue N release. Soil Sci. Soc. Am J. 58(1): 1660-1665.
Brar, B.S., Singh, J., Singh, G. and Kaur, G. 2015. Effects of Long Term Application of Inorganic and Organic Fertilizers on Soil Organic Carbon and Physical Properties in Maize-Wheat Rotation. Agronomy, 5: 220-238.

Chaudhary, S., Dheri, G.S., Brar, B.S. 2017. Long-term effects of NPK fertilizers and organic manures on carbon stabilization and management index under rice-wheat cropping system. Soil Tillage Res. 166: 59-66.

Chinnamani, N., Kumar, A, Hemalatha, M. and Suresh, S. 2018. Influence of Integrated Nutrient Management Practices on Yield and Nutrient Uptake of Rice under System of Rice Intensification. Int $\mathbf{J}$ Adv Agri Sci Tech 2(1): 54-61.

Datta, S.K., Buresh, I.R.J. and Mamaril, C.P. 2010. Increasing nutrient use efficiency in rice with changing needs. Ferti Res. 26: 157-167.

Deenik JL, McClellan T, Uehara G, Antal MJ, Campbell S. 2010. Charcoal volatile matter content influences plant growth and soil nitrogen transformations. Soil Sci Soc Am J 74:1259-1270.

Devkota, S., Panthi, S., and Shrestha, J. 2019. Response of rice to different organic and inorganic nutrient sources at Parwanipur, Bara district of Nepal. J Agri Nat Res, 2(1): 53-59

Ding, Y., Liu, Y., Liu, S., Li, Z., Tan, X., Huang, X., Zeng, C., Zhou, Lu., Zheng, B. 2016. Biochar to improve soil fertility. A review. Agron. Sustain. Dev. 36: 36DOI 10.1007/s13593-016-0372-z

Dixit, K. G., and Gupta, B. R. 2000. Effect of farmyard manure, chemical and biofertilizers on yield and quality of rice (Oryza sativa) and soil properties. J Indian Soc Soil Sci, 48: 773-780.

Dubey,R., Sharma, R.S., and Dubey, D.P. 2014.Effect of organic, inorganic and integrated nutrient management on crop productivity, water productivity and soil properties under various rice-based cropping systems in Madhya Pradesh, India. Int. J. Curr. Microbiol. App.Sci., 3(2): 381-389

Esfahani, A.A. Niknejad, Y., Fallah, H., Dastan, 
S. 2018. Effect of mineral and biological fertilizers on the quantitative and the qualitative parameters of rice cultivars. Appl Ecol environ Res.16 (6):7377-7393

Gangmei, T.P., and George, P.J. 2017. Black rice CV. 'Chakhao Amubi' (Oryza sativa L.) Response to organic and inorganic sources of nutrients on growth, yield and grain protein content. $\mathrm{J}$ Pharmaco Phytochem. 6(4): 550-555

Gaud, V.V. 2004. Production potential and economic feasibility of rice based cropping system under integrated nutrient management. Ph.D. thesis submitted to Navsari Agricultural University, Navsari.

Han, S.H., Young, J., Hwang, J., Kima, S.B. and Parka, B. 2016. The Effects of Organic Manure and Chemical Fertilizer on the Growth and Nutrient Concentrations of Yellow Poplar (Liriodendron tulipifera Lin.) in a Nursery System. Forest Sci Tech, 12: 137-143.

Iqbal,A., He, L., Khan, A., Wei, S., Akhtar, K., Ali,I., Ullah, S., Munsif, F., Zhao, Q., and Jiang, L. 2019. Organic Manure Coupled with Inorganic Fertilizer: An Approach for the Sustainable Production of Rice by Improving Soil Properties and Nitrogen Use Efficiency. Agronomy 9, 651; doi:10.3390/agronomy9100651

Issaka R.N., Buri M. M., Nakamura S. and Tobita S. 2014. Comparison of Different Fertilizer Management Practices on Rice Growth and Yield in the Ashanti Region of Ghana. Agri Forestry Fisheries. 3(5): 374-379.

Jahan, M., Hossain, A., Timsina, J., Sarkar, M.A.R, Salim, M., Farooq, M., Das, S., Chaki, A.K. and Hossai, M.M. 2019. Productivity, nutrient balance and economics of monsoon rice under different nutrient management practices in two agro-eco logical zones of Bangladesh. Open Agri 4(1): 24-40

Jien SH, Wang CS. 2013. Effects of biochar on soil properties and erosion potential in a highly weathered soil. Catena 110:225233.

John, P.S., George, M. and Jacob, R.Z.2001. Nutrient mining in agro-climatic zones of Kerala, Ferti News 46:45-52 and 55-57.
Jones DL, Rousk J, Edwards-Jones G, DeLuca TH, Murphy DV. 2012. Biochar-mediated changes in soil quality and plant growth in a three year field trial. Soil Biol Biochem 45:113-124.

Kammann CI, Schmidt HP, Messerschmidt N, Linsel S, Steffens D,Müller C, Koyro HW, Conte P, Joseph S. 2015. Plant growth improvement mediated by nitrate capture in co-composted biochar. SciReport 5:11080. doi: 10.1038/srep1 1080

Khan AR, Chandra D, Nanda P, Singh SS, Ghorai AK, Singh SR et al., 2001. Sustainable rice production through nutrient management in coastal region of India. National seminar on water and land management including CAD for socioeconomic upliftment of north eastern region. NERIWALM, Guwahati. 22 (23):70-73.

Khan M. U., Qasim M. and Khan I. U. 2007. Effect of Integrated Nutrient Management on Crop Yields in Rice-Wheat Cropping System. Sarhad J. Agric. 23 (4):10201026.

Kharub, A.S., Sharma, R.K., Mongia, A.D., Chhokar, R.S., Tripathi, S.C., Sharma, V.K. 2004. Effect of rice (Oryza sativa) straw removal, burning and incorporation on soil properties and crop productivity under rice-wheat (Triticum aestivum) system. Indian J. Agric. Sci. 74: 295-299.

Koushal S.,Sharma A.K. and Singh A.2011. Yield Performance, Economics and Soil Fertility through Direct and Residual Effects of Organic and Inorganic Sources of Nitrogen as Substitute to Chemical Fertilizer in Rice-Wheat Cropping System. Res J Agri Sci, 43 (3):189-193.

Krishnakumar, S. and Haefele, S. 2013. Integrated nutrient management and LCC based nitrogen management on soil fertility and yield of rice (Oryza Sativa L.). Acad J. 8(41): 2059-2067.

Kumar, A., Meena, R.N., Yadav, L. and Gilotia, YK. 2014. Effect of organic and inorganic sources of nutrient on yield, yield attributes and nutrient uptake of rice. The bioscane 9(2): 595-597.

Kumar, P. 2010. Effect of integrated nutrient 
management on growth, yield and quality of aromatic rice (Oryza sativa L.). Ph.D. thesis submitted to Rajendra Agricultural University.

Kumari, R., Kumar, S., Kumar, R., Das, A., Kumari, R., Choudhary, C.D., Sharma, R.P. 2017. Effect of long-term integrated nutrient management on crop yield, nutrition and soil fertility under ricewheat system. J. Appl. Nat. Sci. 9: 18011807.

Kumari, S., Chattopadhyaya, N., Mandal, J. and Singh, M., 2017. Integrated Nutrient Management boost the soil biological properties in rice rhizosphere. $J$ Crop Weed,13(1): pp.116-124.

Larijani B. A. and Hoseini S.J. 2012. Comparison of Integrated Chemical and Organic Fertilizer Management onRice Growth and Yield under System of Rice Intensification (SRI). Int J Agron Plant Prod. 3:726-731.

Liu, Y., Ding, Y.F., Wang, Q.S., Meng, D.X., Wang, S.H.2011. Effects of nitrogen and 6-benzylaminopurine onrice tiller bud growth and changes in endogenous hormones and nitrogen. Crop. Sci. 51: 786-792.

Mahajan A and Gupta R D. 2009. Integrated nutrient management (INM) in a sustainable rice-wheat cropping system. Springer Science \& Business Media. pp 140.

Mahajan, A., Bhagat, R.M., Gupta, R.D. 2008. Integrated nutrient management in sustainable rice-wheat cropping system for food security in India. SAARC J. Agric. 6:1-13.

Mahajan, A., Sharma, R. 2005. Integrated nutrient management (INM) system: Concept, need and future strategy. Agrobios. Newsl. 4:29-32.

Mahmud AJ, Shamsuddoha ATM, Haque MN. 2016. Effect of Organic and Inorganic Fertilizer on the Growth and Yield of Rice (Oryza sativa L). Nat Sci. 14(2):4554].

Mallikarjun, M. and Maity, S.K. 2018. Effect of Integrated Nutrient Management on Soil Biological Properties in Kharif Rice. Int $J$ CurrMicrobiol App Sci. 7(11): 1531-1537
Mannade, A.K., Tedia, A.K., Tomar, G.S. and Kumar, R. 2017. Evaluate the effect of SSNM on yield and yield attributing parameters of rice in vertisol. Int. J. Chem Stu 5(4): 2082-2085.

Mehdi S.M., Sarfraz M., Abbas S.T. and Shabbir G. 2011. Integrated Nutrient Management for Rice-Wheat Cropping System in A Recently Reclaimed Soil. Soil Environ. 30(1): 36-44.

Moe, K., Htwe, A.Z., Phong Thu, T.T., Kajihara, Y., and Yamakawa, T. 2019.Effects on NPK Status, Growth, Dry Matter and Yield of Rice (Oryza sativa) by Organic Fertilizers Applied in Field Condition. Agriculture $\quad 9, \quad 109$; doi:10.3390/agriculture9050109

Moe, K., Mg,W., Win, K.K., and Yamakawa, T. 2017. Combined Effect of Organic Manures and Inorganic Fertilizers on the Growth and Yield of Hybrid Rice (Palethwe-1). Sci Res 8(5):1022-1042

Mungai, N.W., Bationo, A. and Waswa, B. 2009. Soil Properties as Influenced by Soil Fertility Management in Small Scale Maize Farms in Njoro, Kenya. J Agron, 4: 131-136.

Naidu, K.D., Radder, B.M., Patil, P.L., Hebsur, N.S. and Alagundagi, S.C. 2009. Nutrient uptake and residual fertility of chilli $(\mathrm{Cv}$. byadgi dabbi) in a Vertisols. Karnataka $J$ Agri Sci, 22 (2): 306-309.

Naresh R K., et al., 2015. Tillage crop establishment strategies and soil fertility management: resource use efficiencies and soil carbon sequestration in a ricewheat cropping system. Ecol Environ \& Conserv., 21: S121-S128.

Nelissen V, RuysschaertG,Manka'Abusi D, D'Hose T, De Beuf K, Al-Barri B, Cornelis W, Boeckx P. 2015. Impact of a woody biochar on propertiesof sandy loam soil and spring barley during a twoyear field experiment. Eur J Agron 62:6578.

Nyalemegbe, K.K., Oteng, J.W. and Brempong, S.A. 2009. Integrated Organic-Inorganic Fertilizer Management for Rice Production on the Vertisols of the Accra Plains of Ghana. West Africa J Appl Eco, 16: 23-33. 
Paikaray, R.K., Mahapatra, B.S., Sharma, G.L. 2002. Effect of organic and inorganic sources of nitrogen on productivity and soil fertility under rice (Oryza sativa)wheat (Triticum aestivum) crop sequence. Indian J. Agric. Sci. 72: 445-448.

Pandey, N., Sarawgi, A. K., Rastogi, N. K., and Tripathi, R. S. 1999. Effect of farmyard manure and chemical $\mathrm{N}$ fertilizer on grain yield and quality of scented rice (Oryza sativa) varieties. Indian J AgriSci, 69, 621-623.

Pandey, N., Verma, A. K., Anurag and Tripathi, R. S. 2007. Integrated nutrient management in transplanted hybrid rice (Oryza Sativa L.). Indian J. of Agron. 52(1): 40-42.

Peake LR, Reid BJ, Tang X. 2014. Quantifying the influence of biocharon the physical and hydrological properties of dissimilar soils. Geoderma. 235:182-190.

Prakash, Y. S., Bhadoria, P. B. S., and Rakshit, T. 2002. Relative efficacy of organic manures in improving milling and cooking quality of rice. International Rice Research Notes, 27, 43-44.

Prasad, B., Prasad, J. and Prasad, R. 1995. Nutrient management for sustained rice and wheat production in calcareous soil amended with green manures, organic manure and zinc (ENG). Fertilizer News 40(3): 39-41.

Quyen, N. V., and Sharma, S. N. 2003. Relative effect of organic and conventional farming on growth, yield and grain quality of scented rice and soil fertility. Archiv Agron Soil Sci, 49: 623-629.

Ramalakshmi, Ch. S. Rao, P. C., Sreelatha, T., Mahadevi, M., Padmaja, G., Rao, P. V. and Sireesha, A. 2012. Nitrogen use efficiency and production efficiency of rice under rice-pulse cropping system with integrated nutrient management. $J$. Rice Res. 5(1-2): 42-51.

Ranjitha P. Sri., Kumar R. M., and Jayasree G.2013.Evaluation of Rice (Oryza sativa L.) Varieties and Hybrids in Relation to Different Nutrient Management Practices for Yield, Nutrient Uptake and Economics in SRI. Annals Bio Res. 4 (10):25-28.

Rao, S.A.V., Prasad, P.V.N. and Venkateswarlu,
B. 2006. Synergistic influence of nitrogen and zinc on grain yield and quality of rice (Oryza sativa L.). (In) Proceedings of National Symposium on Conservation Agriculture and Environment, 2628October 2006, Banaras Hindu University, Varanasi, Uttar Pradesh, pp. 181-182

Saba, N.,Awan, I.U., Baloch, M. S., Shah, I. H., Nadim, M. A. and Qadir J .2013. Improving Synthetic Fertilizer Use Efficiency through Bio-Fertilizer Application in Rice. Gomal Uni J Res., 29(2).pp.33-38.

Saha, S., Pandey ,A.K., Gopinath, K.A., Bhattacharaya, R., Kundu, S., and Gupta, H.S. 2007.Nutritional quality of organic rice grown on organic composts.Agron. Sustain. Dev. 27: 223-229

Sarker, U.K., Uddin, M.R., Sarkar, M.A.R., Salam, M.A., Khairul, A. 2017. Influence of organic and inorganic nitrogen on the growth and yield of irrigated rice. AsianAus. J. Biosci. Biotech. 2: 9-23.

Satyanarayana V., Murthy V. R. K., Vara Prasad P. V. and Boote K. J.2002. Influence of Integrated Use ofFarmyard Manure and Inorganic Fertilizers on Yield and Yield Components of Irrigated Lowland Rice. J Plant Nutr. 25(10): 2081-2090.

Schmidt HP, Pandit BH, Martinsen V, Cornelissen G, Conte P, Kammann CI. 2015. Fourfold increase in pumpkin yield in response to low-dosage root zone application of urine-enhanced biochar to a fertile tropical soil. Agriculture 5: 723741.

Sharada. P, Sujathamma P. 2018. Effect of Organic and Inorganic Fertilizers on the Quantitative and Qualitative Parameters of Rice (Oriza sativa L.). CurrAgri Res. 6(2). doi: http://dx.doi.org/10.12944/ CARJ.6.2.05

Sharma R .2013. Effect of Long Term Integrated Nutrient Management System on Soil and Crop Productivity inRice-Wheat Crop Sequence. PhD Dissertation. pp.155.

Sharma, S.N. 2002. Nitrogen management in relation to wheat (Triticum aestivum) residue management in rice (Oryza sativa). Indian J AgriSci 72:449-452. 
Singh, N.P., Singh, M.K., Tyagi, S. and Singh, S.S. 2018. Effect of Integrated Nutrient Management on Growth and Yield of Rice (Oryza sativa L.). Int $J$ CurrMicrobiolApplSci7(1): 3671-3681.

Spokas KA, Novak JM, Stewart CE, Cantrell KB, Uchimiya M, DuSaire MG, Ro KS. 2011. Qualitative analysis of volatile organic compounds on biochar. Chemosphere 85:869-882.

Srivastava, P., Srivastava, P. C., Singh, U. S. and Shrivastava, M. 2009. Effect of integrated and balanced nutrient application on soil fertility, yield and quality of basmati rice. Archiv Agron Soil Sci, 55: 265-284.

Subbiah, S. and Kumarswamy, K. 2000. Effect of different manure fertilizer schedules on the yield and quality ofrice and on soil fertility. Fertilizer News. 45(10): 61-62 \& 65-67.

Sutaliya, R. and Singh, R.N. 2005. Effect of planting time, fertility level and phosphate- solubilizing bacteria on growth, yield and yield attributes of winter maize (Zea mays) under rice (Oryza sativa)- maize cropping system. Indian J Agron50(3):173-75

Tharmaraj, K., Ganesh. P., Kolanjinathan. K., Suresh Kumar. R. and Anandan A. 2011. Influence of vermicompost and vermiwash on physico chemical properties of rice cultivated soil. Curr Bot, 2(3): 18-21.

Tiwari, A., Singh, N.B. and Kumar, A. 2017. Effect of Integrated nutrient management on soil properties, yield and economics of rice (Oryza sativa L.). Res. Environ. Life Sci. 10(7): 640-644.

Virdia, H.M. and Mehta, H.D. 2008. Integrated
Nutrient Management in Transplanted Rice (Oryza sativa L.). Int J Chem Stu 5 (3): $82-87$

Walia, M.K., Walia, S.S. and Dhaliwal, S.S. 2010. Long Term Effect of Integrated Nutrient Management of Properties of Typic Ustochrept after 23 Cycles of Irrigated Rice (Oriza sativa L.) Wheat (Triticum aestivum L.) System. J Sust Agri, 34:724740.

Wang Y, Yin R, Liu R. 2014. Characterization of biochar from fast pyrolysis and its effect on chemical properties of the tea garden soil. J Anal Appl Pyrol 110:375-381.

Wu, W., Ma, B. 2015. Integrated nutrient management (INM) for sustaining crop productivity and reducing environmental impact: A review. Sci. Total Environ. (512-513): 415-427

Xu G, Sun J, Shao H, Chang SX. 2014. Biochar had effects on phosphorus sorption and desorption in three soils with differing acidity. Ecol Eng 62:54-60.

Yadav M.P., Aslam M. and Kushwaha S.S. 2005. Effect of integrated nutrient management on rice (Oryza sativa) wheat (Triticum aestivum) cropping system in central plains zone of Uttar Pradesh. Indian $J$ Agron., 50 (2):89-93.

Yadav, D.S., Kumar, A. 2000. Integrated nutrient management in rice-wheat cropping system under eastern Uttar Pradesh. Indian Farm. 50: 28-30.

Yoshida, S.1981. Fundamental of Rice Crop. Science, $1^{\text {st }}$ Ed., International Rice Research Institute: Los Baños, Laguna, Philippines, p. 269.

\section{How to cite this article:}

Shipra Yadav, Mohan Lal, R.K. Naresh, R.B. Yadav, Ashok Kumar Yadav, K.G. Yadav, Rahul Kumar, M. Sharath Chandra and Pradeep Rajput. 2019. Effect of Organic and Inorganic Nutrient Sources on Productivity, Grain Quality of Rice and Soil Health in North-West IGP: A Review. Int.J.Curr.Microbiol.App.Sci. 8(12): 2488-2514.

doi: https://doi.org/10.20546/ijcmas.2019.812.293 